\title{
Het verlangen naar zuiverheid : een essay over Duitsland
}

Citation for published version (APA):

Labrie, A. (1994). Het verlangen naar zuiverheid : een essay over Duitsland. Rijksuniversiteit Limburg. https://doi.org/10.26481/spe.19940204al

Document status and date:

Published: 04/02/1994

DOI:

10.26481/spe.19940204al

Document Version:

Publisher's PDF, also known as Version of record

\section{Please check the document version of this publication:}

- A submitted manuscript is the version of the article upon submission and before peer-review. There can be important differences between the submitted version and the official published version of record.

People interested in the research are advised to contact the author for the final version of the publication, or visit the DOI to the publisher's website.

- The final author version and the galley proof are versions of the publication after peer review.

- The final published version features the final layout of the paper including the volume, issue and page numbers.

Link to publication

\footnotetext{
General rights rights.

- You may freely distribute the URL identifying the publication in the public portal. please follow below link for the End User Agreement:

www.umlib.nl/taverne-license

Take down policy

If you believe that this document breaches copyright please contact us at:

repository@maastrichtuniversity.nl

providing details and we will investigate your claim.
}

Copyright and moral rights for the publications made accessible in the public portal are retained by the authors and/or other copyright owners and it is a condition of accessing publications that users recognise and abide by the legal requirements associated with these

- Users may download and print one copy of any publication from the public portal for the purpose of private study or research.

- You may not further distribute the material or use it for any profit-making activity or commercial gain

If the publication is distributed under the terms of Article $25 \mathrm{fa}$ of the Dutch Copyright Act, indicated by the "Taverne" license above, 


\section{Het verlangen naar zuiverheid}

Een essay over Duitsland

A. Labrie 
Unlversiteltsblbllotheek

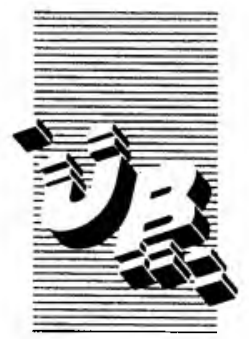

De uitleentermijn verstrijkt op:

\section{$966117 n \pi 62$}

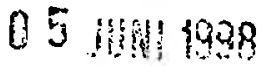

08 NOV 2000

.13 Juir 2002

25 JUN 2002

Rijksuniversiteit Limburg

Postbus 616

6200 MD Maastricht

Gelieve deze publicatie tijdig te retourneren of (telefonisch) verlenging van de uitleentermijn aan te vragen. 


\title{
$\mathrm{mr}$ \\ VAA \\ 217
}

\section{HET VERLANGEN NAAR ZUIVERHEID}

\author{
Een essay over Duitsland
}

Rede

in verkorte vorm uitgesproken bij de aanvaarding

van het ambt van hoogleraar

Maatschappij- en Cultuurgeschiedenis aan de Faculteit der Cultuurwetenschappen

van de Rijksuniversiteit Limburg op

4 februari 1994

door

A. Labrie 


\section{Voor Nanon en Charlotte}

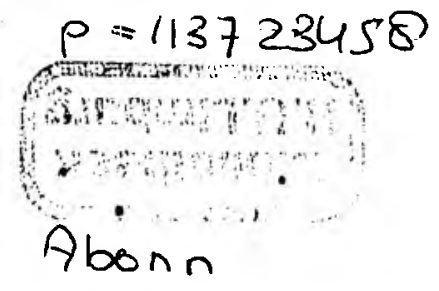

"Nichts ist ermüdender, als die Mannigfaltigkeit der Wirklichkeit, die zahllose Menge ihrer Zufälligkeiten, wenn nicht aus ihr am Ende eine Idee hervorstrahlt.."

Wilhelm von Humboldt 
Mijnheer de rector, dames en heren,

In zijn roman Der Wanderer zwischen beiden Welten uit 1916 schetst de Duitse schrijver Walter Flex de belevenissen van een groep soldaten ten tijde van de Eerste Wereldoorlog. Het boek is een eerbetoon aan Flex' gesneuvelde kameraad Ernst Wurche, die dan ook de hoofdfiguur is in dit verhaal. Wurche, afkomstig uit de Wandervogel-beweging, wordt door Flex verheven tot het symbool van de Duitse jeugd, die een betere toekomst zal voorbereiden. Reinheit is daarbij het sleutelwoord. Wurche heeft "reine Augen", zijn stem is "hell und rein", uit zijn woorden spreekt "ein reiner, klarer, gesammelter Wille" en "in seiner schlanken Reinheit" gelijkt zijn gestalte op die van een Ganymedes. Wurche is als Nietzsche's Zarathoestra, een Fuhrer die zich door "Blick und Stimme und Gang des Starken und Reinen" van de massa onderscheidt. Zijn leven getuigt op volmaakte wijze van de geest der Wandervogel die wordt samengevat in zijn lijfspreuk: "Rein bleiben und reif wer$d^{\prime \prime}$. Een streven dat tenslotte door de dood wordt bekroond, die de jonge held "mit reinem, stolzem Gesichte" tegemoet treedt."

Herhalingen en metaforen tonen Flex' obsessie met het verschijnsel zuiverheid. Daarmee is dan tegelijk het thema genoemd, dat ik in deze oratie aan de orde wil stellen: het verlangen naar zuiverheid zoals dat zich vanaf het einde van de achttiende eeuw tot aan de vooravond van de Eerste Wereldoorlog in de Duitse geschiedenis heeft gemanifesteerd. Dit verlangen vormt een van de opvallende kenmerken van de Duitse cultuur en is door sommigen ook als zodanig onderkend. Aldus bestempelt Léon Poliakov Duitsland als "het bolwerk van een zuiverheidsideaal". ${ }^{2}$ Die mening wordt ondersteund door Bernard Nuss, die in zijn recent verschenen boek Das Faust-Syndrom opmerkt, dat Duitsers meer dan andere volken

${ }^{1}$ W. Flex, Gesammelte Werke Bd. 1 (München 1936), p. 189-192, 196, 204, 216 en 247-248. Vgl. G.L. Mosse, Nationalism and sexuality. Respectability and abnormal sexuality in modern Europe. (New York 1985), p. 117118.

${ }^{2} \mathrm{~L}$. Poliakov, De arische mythe. Over de bronnen van racisme en de verschillende vormen van nationalisme. (Amsterdam 1979; 1e druk 1971), p. 244. 
hechten aan Reinheit, Reinlichkeit en Sauberkeit. Zij zouden daarin zelfs zover gaan, dat men gemakkelijk van een collectieve obsessie zou kunnen spreken. De hoogste deugd wordt hier toegekend aan de reine Seele, een reines Gewissen en Reinheit des Charakters; termen die oprechtheid, integriteit en authenticiteit impliceren. En die innerlijke deugd zou dan worden gereflecteerd in de Sauberkeit van een gezonde, hygiënische leefwijze en een propere huishouding. ${ }^{3}$

De vraag, die uit het voorgaande voortvloeit, luidt: "Vanwaar dit verlangen naar zuiverheid?" Ik heb niet de illusie, dat ik die vraag binnen het bestek van deze oratie afdoende kan beantwoorden. We begeven ons dan ook op een nog vrijwel maagdelijk terrein van onderzoek, dat hier ten hoogste kan worden verkend. Mijn doel is dit terrein nader af te bakenen, en het belang te tonen van een thema, dat ons in staat stelt om verschijnselen, die doorgaans onafhankelijk van elkaar worden bestudeerd, in een onderling verband te plaatsen. In die zin heeft deze oratie ook een programmatisch karakter: het betreft het begin van een nieuw project, dat zich beslist niet tot het Duitse Reinheitsideal behoeft te beperken.

Een korte inleiding moet hier volstaan om het karakter van dit onderzoek en enige daarmee verbonden problemen aan te duiden. (I) Vervolgens zal ik ingaan op het onderwerp zelf: op de rol van het Reinheitsideal in de moderne Duitse geschiedenis. Aan de hand van enige voorbeelden zal ik proberen aan te tonen, hoezeer het verlangen naar zuiverheid verschillende politieke en levensbeschouwelijke stromingen doordringt en verbindt. (II) Deze voorbeelden leveren de bouwstenen voor een interpretatie, die ongetwijfeld nog een tamelijk speculatief karakter heeft, maar die misschien toch al enig licht kan werpen op de maatschappelijke en psychologische voorwaarden, waaronder het verlangen naar zuiverheid gestalte krijgt. Dit interpretatieschema wordt aan het slot, bij wijze van voorlopige balans, kort geresumeerd. (III)

${ }^{3}$ Vgl. B. Nuss, Das Faust-Syndrom. Ein Versuch uber die Mentalitut der Deutschen. (Bonn/Berlin 1993), p. 88 e.v. 


\section{Zuiverheid als historisch-antropologische categorie}

Zoals gezegd moeten vooraf enige kanttekeningen bij dit onderwerp worden geplaatst:

1. Mijn eerste opmerking betreft de terminologie, waarbij afwisselend de woorden "zuiverheid" en "reinheid" worden gehanteerd. De term "reinheid" verwijst daarbij primair naar het lichaam en de fysieke omgeving. Het begrip "zuiverheid" heeft een bredere betekenis en omvat niet alleen de fysieke, maar ook de intellectuele en spirituele aspecten van het verschijnsel.

2. Mijn tweede opmerking gaat over het karakter van deze studie. Het verlangen naar zuiverheid manifesteert zich in vele, vaak zeer verschillende vormen. Voorstanders van sociale hygiëne en Lebensreform, eugenetici en rassenhygiënisten, nationalisten en pleitbezorgers van culturele en spirituele regeneratie: zij allen worden geleid door een idee van zuiverheid. De verschillen tussen deze bewegingen zijn zeker niet bijkomstig en in velerlei opzicht zelfs, met name in hun morele en politieke consequenties, essentieel. Maar mijn doel is hier toch in de eerste plaats gericht op de overeenkomsten en verborgen relaties.

Dat zoeken naar ondergrondse verbindingen verschaft dit onderzoek een min of meer "archeologisch" karakter. Het verlangen naar zuiverheid toont zich zelden in een naakte vorm. Het onderscheid tussen rein en onrein, zuiver en onzuiver doordringt het denken van uiteenlopende stromingen, maar behoort niet tot de ideologie in strikte zin. De termen zelf worden zelden geproblematiseerd, vormen niet de inzet van filosofische en wetenschappelijke debatten, en treden zo nauwelijks aan de oppervlakte van het bewustzijn. De term "zuiverheid" verwijst dan ook niet naar een welomschreven idee, maar toont slechts het topje van een complex van associaties, die zich in eerste instantie aan het gezicht onttrekken. In die zin behoort de analyse van de concepten zuiverheid en reinheid tot de "archeologie" van de ideeëngeschiedenis. Het betreft categorieën, die het denken in hoge mate bepalen, maar die zelf niet of nauwelijks het object vormen van bewuste reflectie.

3. In de derde plaats moet beknopt aandacht worden besteed aan de literatuur. Het verlangen naar zuiverheid vormde tot op heden geen onderwerp van historisch onderzoek. Wij beschikken over studies 
over het Idealisme, over Bildung, hygiënisme, sexualiteit, nationalisme en racisme. Maar een geschiedenis van het verschijnsel zuiverheid, dat al deze terreinen doorkruist, ontbreekt vooralsnog. Wie een aanknopingspunt zoekt in de wetenschappelijke literatuur dient veeleer te rade te gaan bij de culturele antropologie. Hier vormt de tegenstelling tussen reinheid en onreinheid een telkens terugkerend thema. Zoals de Franse antropoloog Roger Caillois opmerkt:

"Il n'est guère de système religieux, même entendu au sens large, où les catégories du pur et de l'impur ne jouent un rôle fondamental. ${ }^{4}$

Een korte blik op deze literatuur kan enige gezichtspunten opleveren, die ook het onderzoek naar het Duitse Reinheitsideal kunnen leiden. Van belang is daarbij met name Mary Douglas' constatering, dat reinheidsvoorschriften doorgaans nauw verband houden met de vrees voor verandering, ambiguïteit en transgressies van getrokken grenzen: "dirt is essentially disorder". ${ }^{5}$ Het streven naar reinheid getuigt van het verlangen naar een onwrikbare orde en van de daarmee verbonden angst voor vermenging of -zoals de Franse filosoof Taguieff het noemt- mixofobie. Dat betekent tegelijk dat deze reinheidsvoorschriften niet louter een hygiënische, maar tevens een symbolische functie vervullen. $\mathrm{Zij}$ zijn "analogies for expressing a general view of the social order"; zij dienen, zoals René Girard het uitdrukt, als "een soort camouflage", waarbij sociale relaties in materiële termen worden vertaald. In die zin fungeert met name het lichaam als een symbool voor de gesloten gemeenschap. De verhoogde belangstelling die men in reinheidsvoorschriften in het algemeen kan opmerken voor lichamelijke

${ }^{4}$ R. Caillois, L'homme et le sacre (Paris 1950), p. 37. Vgl. E. Pewzner, L'homme coupable. La folie et la faute en Occident. (Paris 1992), p. 192, waar de schrijfster het probleem van onreinheid en bezoedeling bestempelt als "un des grands themes de l'anthropologie culturelle".

5 M. Douglas, Purity and danger. An analysis of the concepts of pollution and taboo. (London/New York 1989; 1e druk 1966), p. 2. Vgl. R. Girard, Violence and the sacred (Baltimore and London 1977; 1e druk 1972), p. 49 e.v. en 284. 
openingen, excrementen en afscheidingen (zoals haar en nagels) -dat wil zeggen: voor die zones, waar de grenzen tussen het eigen lichaam en de omgeving vervagen- correspondeert met de zorg om de innerlijke eenheid van de gemeenschap tegenover de gevaren van de buitenwereld te handhaven. ${ }^{6}$

Rein is datgene, wat én is met zichzelf en "ce dont l'essence n'est melée de rien qui l'altère et qui l'avilisse". ${ }^{7}$ Reinheid wordt geassocieerd met kracht, gezondheid, moed en harmonie. Het onreine is daarentegen het product van contaminatie, die leidt tot ziekte, zwakheid, ontbinding en dood. Het zuivere versterkt de interne orde en cohesie, die door de aanraking met het onzuivere juist worden verstoord. In deze voorstelling is de gemeenschap, zoals Caillois opmerkt, als een verlicht centrum, dat aan de periferie door chaos en duisternis wordt bedreigd. Het onreine is het andere en het vreemde, dat zich van buitenaf in de gemeenschap indringt om zich hier met de kracht van een besmettelijke epidemie te verbreiden. ${ }^{8}$ Het onreine vertegenwoordigt zo echter tegelijk een hogere macht, die naast vrees en afschuw ook verering en ontzag oproept. Die ambivalentie komt onder meer tot uitdrukking in het verschijnsel van de zondebok. In het Grieks hebben de termen pharmakos en katharma, waarmee de zondebok wordt aangeduid, tevens de betekenis van reiniging en genezing. De zondebok, die alle schulden van de gemeenschap op zich neemt, is in de hoogste mate onrein en als zodanig het voorwerp van verachting. Tegelijk

${ }^{6}$ Vgl. M. Douglas, o.c., p. 3, 34 en 114-129; R. Girard, o.c., p. 28; P.-A. Taguieff, La force du prejugé. Essai sur le racisme et ses doubles. (Paris 1990; le druk 1987), p. 338 e.v. Zie ook: L. Dumont, Homo hierarchicus. The caste system and its implications. (Chicago and London 1980; 1e druk 1966), p. $46-47$ en 60.

${ }^{7}$ R. Caillois, o.c., p. 38.

${ }^{8}$ Vgl. R. Caillois, o.c., p. 61-63; M. Douglas, o.c., p. $95-96$ en 121; R. Girard, o.c., p. 270 e.v. Zie ook: M. Eliade, Het heilige en het profane (Amsterdam 1977; 1e druk 1957), p. 30-40. Over de relatie tussen dood en onreinheid: E. Feldman, Biblical and post-biblical defilement and mourning: law as theology (New York 1977), m.n. p. 49 e.v.: "Truly, death itself is the 'ultimate category' of tum'ah (onreinheid-A.L.)." 
echter zuivert hij -zoals Oedipus- door zijn offer deze gemeenschap en wordt hij vanwege deze macht, die een wedergeboorte bewerkstelligt, vereerd. Het onderscheid tussen reinheid en onreinheid is derhalve geenszins eenduidig. Soms lijkt zelfs sprake te zijn van een volledige omkering zoals in het geval van de heilige Elisabeth, die de nabijheid zoekt van besmettelijke zieken en schurftige kinderen, slaapt bij de varkens en zich bij voorkeur in de modder wentelt. Zich te dompelen in zoveel onreinheid is hier slechts het kenteken van een hogere zuiverheid, die volgens de hagiograaf wordt bevestigd door de fijne geur, die haar lichaam na haar dood verspreidde. ${ }^{9}$

4. Gezien het voorgaande maakt het Reinheitsideal deel uit van een wijd verbreid patroon, volgens hetwelk mensen met een verschillende culturele achtergrond hun wereld ordenen en classificeren. Het verlangen naar zuiverheid is dan ook geenszins een "typisch Duits" verschijnsel. Tegelijk moet hier echter -dat is de strekking van mijn vierde opmerking- worden gewezen op enige belangrijke verschillen tussen zogenaamd "primitieve" beschavingen en een moderne westerse cultuur. Twee punten lijken mij daarbij van bijzonder belang.

In de eerste plaats is het verlangen naar zuiverheid ten nauwste verbonden met religieuze voorstellingen. De westerse perceptie van het verschijnsel wordt dan ook in belangrijke mate bepaald door de christelijke traditie. Karakteristiek voor het christendom is daarbij de relatie tussen onzuiverheid en persoonlijke schuld. Het christendom verdiept de notie van onzuiverheid, aangezien het deze verbindt met het Kwaad dat sedert de zondeval inherent is aan de mens zelf. In primitieve, heidense culturen is onreinheid het gevolg van machten, die van buitenaf op de mens inwerken. Daarentegen leidt de idee van de erfzonde, waarmee ieder is bevlekt, tot een verinnerlijking van het Kwaad en de daarmee verbonden onzuiverheid. Zoals Evelyne Pewzner opmerkt in haar boek L'homme coupable:

${ }^{9}$ Vgl. R. Caillois, o.c., p. 40,49 en 52-56; R. Girard, o.c., p. 68 e.v. (zijn briljante analyse van Sophocles' Oedipus rex), 95, 104 e.v. en 257; R. Parker, Miasma. Pollution and purification in early Greek religion. (Oxford 1983), p. 258 e.v.; M. Onfray, De kunst van het genieten. Pleidooi voor een hedonistisch materialisme. (Baarn 1993), p. 132-133. 
"Si le péché a 'souille' le genre humain, la souillure dont il est question alors atteint l'être dans son intimité la plus profonde.. ${ }^{n 10}$

De tegenstelling tussen het Goede en het zuivere enerzijds en het Kwade en het onzuivere anderzijds komt in hoge mate overeen met de scheiding tussen ziel en lichaam. De ziel is de zuivere kern van de persoon. $\mathrm{Zij}$ is de goddelijke vonk, die tracht terug te keren naar haar oorsprong, maar daarbij wordt gehinderd door het lichaam, waarin zij als een balling is opgesloten. De taak van de christen is, zich te bevrijden van de lichamelijke behoeften en begeerten die zijn ziel verontreinigen. Het ideaal is de zuivere ziel, die zich -zoals Lodewijk de Heilige het uitdrukt- "van de lepra van het lichaam" heeft ontdaan: de engel, die -volgens Marsiglio Ficino- niet is aangetast door de "bezoedelingen van de materie". De strijd tegen de vermenging met het lichaam dwingt tot een ascetische leefwijze, waarbij kuisheid en onthouding als de hoogste deugden gelden en eeuwige verlossing de inzet vormt. Die strijd speelt zich af in het afzonderlijke individu, dat zelf de verantwoordelijkheid draagt om de ziel van de zonden van het lichaam schoon te wassen. En die verantwoordelijkheid en het daarmee verbonden schuldgevoel worden nog slechts verhoogd, wanneer dit individualiteitsbesef, geconcentreerd rond de christelijke notie van de ziel, zich mettertijd verdiept, en wel met name in het protestantisme, waar de individuele ziel alleen staat voor haar God. ${ }^{11}$

Dit dualisme tussen ziel en lichaam en de daarmee verbonden noties van zonde, schuld, individualiteit en verlossing zijn in hoge mate specifiek voor de christelijke traditie en de daaruit voortgekomen voorstelling van zuiverheid. ${ }^{12}$ Die voorstelling lijkt echter in

${ }^{10}$ E. Pewzner, o.c., p. 113. Vgl. ibid., p. 18-19, 89 en 169.

11 Vgl. E. Pewzner, o.c., p. 47-48, 75, 157 e.v., 173 e.v. en 190; M. Onfray, o.c., p. 140; J. Le Goff, De cultuur van middeleeuws Europa (Amsterdam 1987), p. 443.

${ }^{12}$ Wel treft men in sommige religieuze en filosofische bewegingen van de klassieke oudheid -b.v. in het platonisme- aanzetten in deze richting: vgl. M. Eliade, A history of religious ideas. Volume 1: From the Stone Age to the Eleusian Mysteries. (London 1978), hoofdstuk 15 en Volume 2: From Gautama Buddha to the triumph of Christianity (London 1984), hoofdstuk 22. 
nog een ander opzicht te verschillen van niet-westerse opvattingen. De westerse idee van zuiverheid is immers geenszins eenduidig. Op grond van verspreide gegevens mag worden aangenomen, dat zij zich in de loop der tijd heeft ontwikkeld en derhalve, afhankelijk van plaats en sociaal-culturele voorwaarden, de nodige variëteit vertoont. In dit verband moet in het bijzonder worden gewezen op de beschavingstheorie van Norbert Elias, die -onder meer- nieuw licht heeft geworpen op de geschiedenis van de hygiëne. Op dit terrein lijkt vanaf de zestiende eeuw sprake te zijn van een groeiende zelfdwang, die tot uitdrukking komt in strengere normen ten aanzien van de lichamelijke verzorging, en die zich vanaf het einde van de achttiende eeuw naar buiten keert in een burgerlijk beschavingsoffensief. De opkomst van de burgerlijke samenleving gaat gepaard met een verhoogde sensibiliteit, die onder meer blijkt uit een grotere gevoeligheid voor onaangename geuren. Het spreekt vanzelf, dat dit proces van toenemende disciplinering niet zonder meer kan worden begrepen in termen van religie en veeleer moet worden gezien als onderdeel van een bredere maatschappelijke ontwikkeling. Daarbij moet dan in het bijzonder worden gewezen op de groei der steden en op de rol van de staat, die in de negentiende eeuw de actieve zorg voor de openbare hygiëne op zich neemt. Dat betekent niet, dat de opkomst van de moderne hygiëne tot dergelijke politieke en sociale factoren kan worden gereduceerd. Zoals gezegd vervullen hygiënische voorschriften niet louter een utilitaristische functie, maar hebben zij tevens een symbolische betekenis. Het reine, gezonde uiterlijk wordt hier opgevat als de weerspiegeling van een zuiver innerlijk. Hygiënische normen zijn, ook in de moderne tijd nog, onlosmakelijk verbonden met morele, sociale en soms ook raciale voorkeuren. De aristocraat, die zich opfrist met parfums, riekt volgens de burger onnatuurlijk, terwijl ook de lagere standen naar zijn oordeel een onaangename geur verspreiden. Evenzo beklaagt de racist zich over de lucht van negers of over de beruchte Foetor Judalcus. Zelfs het reukvermogen blijkt derhalve, zoals Alain Corbin heeft aangetoond, de drager 
van een sociale en culturele code. ${ }^{13}$

5. Het voorgaande levert enige gezichtspunten, op grond waarvan nader historisch onderzoek kan worden aangevangen. De antropologie vestigt de aandacht op het verband tussen het verlangen naar zuiverheid enerzijds en het streven naar orde en de vrees voor vermenging anderzijds. $Z$ ij benadrukt bovendien de symbolische betekenis van dit verlangen, dat altijd is verbonden met wereldbeschouwelijke voorstellingen. Evelyne Pewzner wijst op het belang van de christelijke traditie voor de meer specifiek westerse voorstelling van zuiverheid, die nog in een geseculariseerde vorm het burgerlijke denken bepaalt. De beschavingstheorie van Norbert Elias suggereert tenslotte, dat de westerse opvattingen omtrent zuiverheid en reinheid met de opkomst van de burgerlijke samenleving een scherpere vorm hebben aangenomen; een proces, dat zijns inziens in sociaalhistorische termen dient te worden begrepen. Deze algemene inzichten kunnen dienen als het uitgangspunt voor de navolgende case-study over het moderne Duitse Reinheitsideal.

\section{Zuiverheid en Wedergeboorte: het Duitse Reinheitsideal}

De negentiende eeuw lijkt inderdaad -conform de beschavingstheorie van Elias- een tijd, waarin het onderscheid tussen zuiverheid en onzuiverheid krachtig wordt benadrukt. Naar het oordeel van Alain Corbin wordt deze periode gekenmerkt door "de beklemtoning van het verlangen naar reinheid". Volgens een tijdgenoot, de Engelse schrijver D.H. Lawrence, betreft het hier zelfs é́n van de

13 Elias' theorie wordt b.v. uitgewerkt door G. Vigarello, Le propre et le sale. L'hygiène du corps depuis le Moyen Age (Paris 1985), m.n. p. 10, 46, 69, 125 e.v., 150-151, 157-159 en 191-192; en J. Goudsblom, Civilisatie, besmettingsangst en hygiëne. Beschouwingen over een aspect van het Europese civilisatieproces., in: Amsterdams Sociologisch Tijdschrift jrg. 4, nr. 3 (1977), p. 271-300. Zie voorts: A. Corbin, Pestdamp en bloesemgeur. Een geschiedenis van de reuk. (Nijmegen 1986), b.v. p. 83 e.v. en 185 e.v.; M. Onfray, o.c., p. 105 e.v. Over de rol van de staat: A. de Swaan, Zorg en de staat. "Welzijn, onderwijs en gezondheidszorg in Europa en de Verenigde Staten in de nieuwe tijd". (Amsterdam 1989), hoofdstuk 4; E.S. Houwaart, De hygiënisten. Artsen, staat \& volksgezondheid in Nederland, 1840-1890. (Groningen 1991), m.n. hoofdstuk 4. 
hoofdzonden van de moderne beschaving; "the lie of purity and the little secret" zijn, zoals hij opmerkt, "the greatest of all lies in the modern world". ${ }^{14}$ Het gaat hier duidelijk om een breder verschijnsel, dat in diverse westerse landen kan worden geconstateerd. Desalniettemin lijkt dit verlangen naar zuiverheid zich nog in een versterkte mate in Duitsland te hebben voorgedaan. Hier wordt bovendien duidelijk, dat dit verlangen zich niet beperkt tot een verhoogde belangstelling voor hygiëne, gezondheid en sexuele moraal, maar ten nauwste is verbonden met visioenen omtrent maatschappelijke hervorming en culturele regeneratie.

\section{Bildung en zuiverheid}

Het moderne Duitse Reinheitsideal kan worden getraceerd tot het Idealisme, dat zich aan het einde van de achttiende eeuw in kringen van de geletterde burgerij verbreidt. Het verlangen naar zuiverheid komt hier niet zozeer tot uitdrukking in een opvallend gebruik van de term Reinheit zelf, maar ligt veeleer besloten in een wereldbeschouwing, waarin Bildung als de ware menselijke bestemming geldt. Dit Bildungsideal heeft een sterk individualistisch en esthetisch karakter. Het hoogste doel van de mens is gelegen in de optimale ontplooiing van alle individuele krachten. Het individu, dat zich op deze wijze bildet, is als een kunstenaar, die zichzelf tot een harmonieuze persoonlijkheid vormt. Dit mensideaal wordt voor het eerst geformuleerd in de kringen van het Duitse neo-humanisme rondom Goethe, Schiller, Herder en Wilhelm von Humboldt. Het vormt het uitgangspunt van de onderwijshervormingen die in de jaren 1809-1810 in Pruisen tot stand worden gebracht, en die het onderwijs ook elders in Duitsland diepgaand hebben beïnvloed. En in deze geïnstitutionaliseerde vorm is het Bildungsideal dan ook uitgegroeid tot een factor die het maatschappelijke en culturele

${ }^{14}$ A. Corbin, De verborgen wereld van het individu, in: Ph. Ariès en G. Duby (red.), Geschiedenis van het persoonlijk leven. Deel 4: Van de Franse Revolutie tot de Eerste Wereldoorlog. (Amsterdam 1989), p. 385; D.H. Lawrence geciteerd bij: E.J. Bristow, Vice and vigilance. Purity movements in Britain since 1700. (Dublin 1977), p. 222. 
leven in Duitsland tot in de twintigste eeuw in hoge mate heeft bepaald.

Het Duitse Bildungsidealismus wordt gekenmerkt door de ervaring van een scherpe tegenstelling tussen het eigen innerlijk en de uiterlijke werkelijkheid. Illustratief is in dit verband een brief van Wilhelm von Humboldt, geschreven op 20 maart 1790:

"Wie doch alles Glück in diesem rein Idealischen unsrer Empfindungen, in diesen Individualitäten unsrer Gefühle liegt, wie sich da jeder seine eigene Welt bildet, und wie nur in dieser Heimat ihm wohl ist. Aber ewig strebt die Wirklichkeit außer uns diesem innern Sein entgegen. Solange sie uns nun bloß einengt, entbehren wir bloss einen Teil des Genusses. Wir ziehen uns immer mehr in uns zurück, werden genügsamer und genießender. Aber wenn wir anfangen, außer uns zu wirken, dann zieht uns oft der Strom mit sich fort, wir gehen aus uns heraus, zerstören die heimische Hütte in uns, und in den Palästen, die wir außer uns auftürmen, bleiben wir ewig Fremdlinge. "15

Het hoogste geluk is volgens Humboldt "das reinste Gefuihl des schönsten inneren Seins". De onrustige ziel voelt zich daarentegen "nicht rein oder nicht schön". ${ }^{16}$ De term rein wordt veelal gecombineerd met Schönheit, Gefuhl, met die Idee en das Ideale en behoort zo tot de sfeer van het innerlijk. Het innerlijk is de zetel van de Idee: het zuivere Ik, de kern van de individuele persoonlijkheid en de bron van authenticiteit. $\mathrm{Zij}$ is het Bild Gottes, dat in ieder mens aanwezig is: het sacrale centrum, vanwaaruit het proces van Bildung een aanvang neemt. Zoals Friedrich Schlegel opmerkt:

"Gott werden, Mensch sein, sich bilden sind Ausdrücke, die einerlei bedeuten. ${ }^{.17}$

15 W. von Humboldt aan C. von Dacheröden, 20-3-1790, in: Wilhelm und Caroline von Humboldt in ihren Briefen (Berlin 1906-1916; hrsg. von A. von Sydow) Bd. 1, p. 103.

16 W. von Humboldt aan C. von Dacheröden, 20-9-1790, in: ibid., p. 220.

${ }^{17}$ F. Schlegel, Werke in zwei Banden (Berlin und Weimar 1980) Bd. 1, p. 225. 
Het innerlijk is echter tegelijk een belegerde veste, die door de gevaren van de buitenwereld wordt bedreigd. Als de ware bestemming van het individu vertegenwoordigt de Idee een hogere noodzaak. De buitenwereld wordt daarentegen door Zufall geregeerd. Het individu wordt hier voor een vrijwel onoplosbaar dilemma gesteld. Enerzijds vormt het contact met deze buitenwereld de voorwaarde voor Bildung, aangezien men eerst zo de eigen krachten kan beproeven en ontplooien. Anderzijds wordt de Idee door deze aanraking met de werkelijkheid bezoedeld. Al te gemakkelijk verliest de mens hier het zicht op zijn ware bestemming en verzaakt deze om zogenaamd uiterlijke doeleinden -zoals rijkdom, macht en status- na te streven. Gesteld voor dit probleem, hoe men "in dieser Entfremdung nicht sich selbst verliere", kiest Humboldt voor een vorm van innerweltliche Askese. ${ }^{18}$ De mens moet in de wereld zijn, maar niet van de wereld; hij moet louter "negatief handelen" door geen acht te slaan op het resultaat van zijn werkzaamheid, die namelijk slechts waarde heeft voorzover zij bijdraagt aan zijn Bildung.

Bildung vereist derhalve een voortdurende waakzaamheid. Ware deugd en morele volmaaktheid zijn gelegen in het "rein Geistige". De mens bevindt zich echter in een "Zwitterzustand": geest en lichaam zijn in hem gemengd; hij is een geestelijk wezen, dat door zinnelijkheid en lichamelijke behoeften aan de wereld is geketend. ${ }^{19}$ Zijn werkelijke karakter is dan ook nooit de zuivere afspiegeling van zijn Idee, maar wordt mede bepaald door uiterlijke omstandigheden, die op hem inwerken en hem overleveren aan de macht van het toeval. Bildung is zo het oneindige streven naar een ideaal, dat nooit kan worden bereikt. Dat ideaal kan ten hoogste worden benaderd dankzij de zelfkennis, die het individu in staat stelt "aus diesem verwirten Chaos sich rein herauszufinden und (..)

${ }^{18}$ W. von Humboldt, Gesammelte Schriften Bd. 1-17 (Berlin 1903-1936) Bd. 1 , p. 284.

19 Vgl. ibid., p. 55; W. von Humboldt aan C. von Dacheröden, 18-41815, in: o.c. Bd. 4, p. 533. 
sich rein zu erhalten." 20 Zelfkennis impliceert het vermogen te onderscheiden tussen de ware individualiteit, welke is gelegen in de Idee, en die eigenschappen in het eigen karakter, welke worden bepaald door het toeval. Op grond van dit zelfinzicht kan men het eigen lot controleren, inzoverre men het toeval in zichzelf kan bestrijden. Bildung wordt daarmee in laatste instantie tot een proces van loutering en zuivering, waarbij ieder "seine Eigentümlichkeit aufsuchen und diese reinigen, das Zufällige absondern" moet. ${ }^{21}$

Dit verlangen naar de reine ofwel schone Seele moet binnen zijn politieke en sociaal-psychologische context worden begrepen. In Duitsland bespeurt men vanaf circa 1770 met name onder jonge intellectuelen een groeiend gevoel van onrust en onzekerheid. In hun verzet tegen het absolutisme en de heersende standenmaatschappij beroepen de aanhangers van de Sturm und Drang zich op het gevoel, op spontaneïteit en op de vrijheid van het individu. Ook Humboldt beklaagt zich bij herhaling over zijn angst, melancholie, en gevoelens van innerlijke leegte en verscheurdheid. Die gevoelens corresponderen met het besef van ingrijpende maatschappelijke veranderingen; veranderingen, die zich aanvankelijk vrijwel onzichtbaar en ondergronds voltrekken, maar die met de Franse Revolutie aan het volle daglicht treden. De Franse Revolutie wordt beleefd als een existentiële crisis, waarin alle zekerheden worden weggevaagd; zij markeert naar Humboldt's oordeel een uitbarsting van primitieve gevoelens, waarin alle orde wordt opgelost. De Revolutie toont zo de politieke consequenties van de gevoelscultus, die door de Sturm und Drang werd gepropageerd en waarin ook de jonge Humboldt nog was bevangen. In die situatie van een algehele -zowel innerlijke als uiterlijke- crisis rijst de vraag, hoe het individu "bei dem allgemeinen Wechsel, in welchem Meynungen, Sitten, Verfassungen und Nationen fortgerissen werden" zijn positie

${ }^{20}$ W. von Humboldt, Gesammelte Schriften Bd. 2, p. 97; vgl. ibid., p. 95-96.

${ }^{21}$ W. von Humboldt aan F. Schiller, 23-10-1795, in: Der Briefwechsel zwischen Friedrich Schiller und Wilhelm von Humboldt Bd. 1-2 (Berlin 1962; hrsg. von S. Seidel) Bd. I, p. 191. 
moet bepalen. ${ }^{2}$ En juist in deze situatie wint het streven naar Bildung aan belang. Waar de wereld tot een chaos lijkt te zijn vervallen en het individu alle houvast heeft verloren, beoogt Bildung het herstel van orde. Die orde wordt vanuit de zuivere bron van het diepste innerlijk gecreëerd en heeft zo een volstrekt natuurlijk karakter. Bildung wordt immers geleid door de Idee, die de gevoelens kanaliseert en tot een harmonieus geheel verbindt. En een samenleving van individuen, die zich op deze wijze hebben gevormd, kan zelf slechts een harmonieuze aanblik bieden.

Aldus samengevat kan de opkomst van het Duitse Bildungsidealismus mede worden bezien in het licht van Mary Douglas' theorie omtrent het verband tussen zuiverheid en orde. Bildung beoogt de zuivering van de heersende chaos, waarbij de reine Seele het model vormt voor een nieuwe orde. Tegelijk is Bildung zo, in de termen van Elias, een vorm van "zelfdwang". De drang tot Bildung geeft uitdrukking aan een sterke behoefte tot zelfbeheersing, die namelijk de voorwaarde vormt om het eigen lot te kunnen controleren in een wereld, die -ervaren als de sfeer van Entfremdung- de individuele identiteit bedreigt. Zoals Friedrich Schlegel opmerkt:

"Nichts ist mebr Bedürfnis der Zeit als ein geistiges Gegengewicht gegen die Revolution und den Despotismus, welchen sie durch die Zusammendrängung des höchsten weltlichen Interesse über die Geister ausübt. Wo sollen wir dieses Gleichgewicht suchen und finden? Die Antwort ist nicht schwer; unstreitig in uns.. ${ }^{23}$

Bildung beoogt de creatie van een nieuwe orde. De hoop op regeneratie en Wedergeboorte, die reeds een cruciale rol speelde in het piëtisme, doordringt in een geseculariseerde vorm ook het Bildungsidealismus en zal het verlangen naar zuiverheid ook in zijn latere ontwikkeling begeleiden. Bildung is de terugkeer naar de

${ }^{22}$ W. von Humboldt, Gesammelte Schriften Bd. 2, p. 124.

${ }^{23}$ F. Schlegel, Werke Bd. 1, p. 267. 
zuivere oorsprong, naar de natuurlijke harmonie, die nu op een hoger niveau moet worden hersteld. ${ }^{24}$

Sedert het verschijnen van Winckelmann's Gedanken uber die Nachahmung der griechischen Werke van 1755 gelden de Grieken daarbij als het na te streven voorbeeld. De zuiverheid van het innerlijk wordt hier weerspiegeld in de uiterlijke schoonheid, die volgens Winckelmann verre was verheven boven die van de moderne mens. Winckelmann's opvattingen omtrent het verband tussen geestelijke en lichamelijke schoonheid keren in een afgezwakte vorm terug in het neo-humanistische Bildungsidealismus. Ook voor Humboldt gelden de Grieken als een symbool voor de mensheid "in ihrer zartesten, reinsten und vollkommensten Gestalt". ${ }^{25}$ Maar in het algemeen leggen Humboldt en zijn geestverwanten toch nog de nadruk op de innerlijke kwaliteiten van de Griek, die in dit opzicht het algemeen-menselijke ideaal vertegenwoordigt. Het zal echter niet lang duren, voordat Winckelmann's lofzang op het Griekse uiterlijk een breder gehoor vindt en wordt verbonden met nationalistische en raciale voorstellingen, die binnen het Bildungsidealismus nog geen rol van betekenis spelen.

\section{Zuiverheid, natie, ras}

De verbreiding van het Bildungsideal houdt ten nauwste verband met gevoelens van onzekerheid en discontinuïteit, die door de Franse Revolutie worden opgeroepen. De ingrijpende politieke en sociale veranderingen van de negentiende eeuw hebben dergelijke gevoelens slechts versterkt. Dat geldt ook voor Duitsland. Hoewel de effecten van de Industriële Revolutie hier pas in de tweede helft

${ }^{24}$ Over Bildung als regeneratie: vgl. W. von Humboldt aan C. von Dacheröden, 30-9-1790, in: o.c. Bd. 1, p. 231. Zie b.v. ook G.W.F. Hegel, Enzyklopadie der philosophischen Wissenschaften im Grundrisse (Hamburg 1975), p. 405 (par. 521); idem, Grundlinien der Philosophie des Rechts (Frankfurt a.M. 1982; Werke in zwanzig Bänden, Bd. 7), p. 302 (par. 151 Zusatz).

${ }^{25}$ W. von Humboldt, Gesammelte Schriften Bd. 3, p. 188 en 216. Vgl. J.J. Winckelmann, Kleine Schriften und Briefe (Weimar 1960), p. 31-33 en 44. 
van de negentiende eeuw ten volle zichtbaar worden, betoont met name de intelligentsia zich al vroeg gevoelig voor de veranderingen die elders plaatsvinden en die in toenemende mate ook de Duitse maatschappij binnendringen. Zoals Goethe in 1832, in de laatste brief vóor zijn dood, schrijft:

"Verwirrende Lehre zu verwirrtem Handel waltet über die Welt.. "20

Het centrale probleem, dat door de veranderingen van de negentiende eeuw wordt opgeroepen, betreft het gevoel van identiteit. Identiteit berust in essentie op een besef van continuïteit en van distincties ten opzichte van anderen. In de relatief statische, preindustriële samenleving was deze persoonlijke identiteit vooral een sociaal gegeven, in hoge mate afhankelijk van de geboorte, die het individu een vaste plaats in de maatschappij toewees. De burgerlijke samenleving van de negentiende eeuw berust echter niet langer op het geboorteprincipe en wordt gekenmerkt door een hoge graad van sociale en geografische mobiliteit. In die situatie vormen externe determinanten zoals stand, woonplaats en beroep niet langer het vaste fundament voor een stabiele identiteit. Deze wordt nu veeleer -zoals het Bildungsidealismus illustreert- gezocht in een innerlijk "verborgen zelf", dat schuil gaat achter alle rollen die men in het dagelijks leven speelt. Diezelfde tendens tot verinnerlijking wordt zichtbaar in het sociaal verkeer, dat wordt gekenmerkt door een verlangen naar intimiteit. Men verlangt het herstel van een verloren gewaande Gemeinschaft, die op zuivere relaties van vriendschap, genegenheid of natuurlijke verwantschap moet zijn gebaseerd. De gemeenschap verleent het individu een gevoel van identiteit en geborgenheid; via haar is het opgenomen in een groep, die zich duidelijk van andere onderscheidt. Het grens-concept is, zoals Anthony Cohen opmerkt, essentieel voor een begrip van het verschijnsel "gemeenschap": de gemeenschap definieert zichzelf in relatie tot "significant others", die worden buitengesloten. En juist hier treedt het verlangen naar zuiverheid aan de oppervlakte. De

26 J.W. Goethe aan W. von Humboldt, 17-3-1832, in: Goethes Briefwechsel mit Wilhelm und Alexander von Humboldt (Berlin 1909; hrsg. von L. Geiger), p. 287. 
hechte gemeenschap is immers de zuivere gemeenschap, die door strakke grenzen wordt behoed voor besmetting met vreemde elementen. Die samenhang wordt dan met name zichtbaar, waar het verlangen naar zuiverheid zich verbindt met nationalistische en raciale opvattingen. ${ }^{27}$

In Duitsland ontstaat het nationalisme aan het einde van de achttiende eeuw. De natie heeft hier niet, zoals in Frankrijk en Engeland, een relatief open karakter; zij wordt niet gezien als een primair politieke gemeenschap, waarvan men door de verwerving van het burgerschap lid kan worden, maar veeleer als een natuurlijk gegeven, dat op grond van objectieve, culturele en etnische criteria wordt gedefinieerd. De natie berust in de taal, de zeden en gewoonten, die de gehele denk- en leefwijze van een volk bepalen. ${ }^{28}$ In deze voorstelling heeft de natie een vrijwel gesloten karakter. Vooral na de napoleontische overheersing worden de grenzen tussen de verschillende nationale karakters sterker beklemtoond. De Duitse identiteit wordt nu bijna per negationem afgeleid uit de Franse, die sterk afkeurend wordt beoordeeld. De Fransen zijn frivool, wispelturig, oppervlakkig en materialistisch. De Duitsers worden daarentegen gekenmerkt door Warde, Tugend en door hun verheven Idealisme. De Fransen symboliseren chaos en wanorde, terwijl de Duitsers borg staan voor orde en moraal. De Duitsers worden geprezen als de moderne Grieken; zij vormen de ware Humanitatsnation: een symbool van de zuivere mensheid. ${ }^{29}$

27 Vgl. R. Baumeister, Identity. Cultural change and the struggle for self. (New York/Oxford 1986), p. 15 e.v., 20 e.v. en 29-75; D.J. de Levita, The concept of identity (Paris/The Hague 1965), p. 52-54; R. Sennett, The fall of public man (London/Boston 1986; 1e druk 1977), passim; A. Cohen, The symbolic construction of community (London and New York 1985), p. 12,53 en $110-115$.

${ }^{28}$ Vgl. E. Gellner, Nations and nationalism (Oxford 1983), p. 1, 6-7 en 3638; E.J. Hobsbawm, Nations and nationalism since 1789. Programme, myth, reality. (Cambridge etc. 1990), p. 5 e.v.

${ }^{29}$ Zie b.v. W. von Humboldt, Gesammelte Schriften Bd. 2, p. 217 en 382 e.v.; $B d .4$, p. 27; en $B d$. XIV, p. 463,480 e.v. en 589. 
Dergelijke opvattingen worden rond 1800 door de meerderheid van de Duitse intellectuelen gedeeld. De Duitser is, zoals Schiller schrijft, "der Kern der Menschheit"; hij is, naar het oordeel van Novalis, geroepen om de wereld te verlossen van de kwalen van de moderne samenleving, te weten rationalisme en materialisme. ${ }^{30}$ Eerst in Fichte's Reden an die deutsche Nation uit 1807 en 1808 mondt dit geloof in de eigen culturele superioriteit evenwel uit in een fel nationalisme. Zoals de voornoemde schrijvers schetst ook Fichte een duister beeld van de eigen tijd; de moderne beschaving is als een lijk dat, aangevreten door ziektes, in ontbinding verkeert. Die ziektes -egoïsme, materialisme en zinnelijkheid- komen, daarover bestaat geen twijfel, uit het buitenland. De buitenlandse volken, en bovenal Frankrijk, verkeren in een staat van verval. Dat feit wordt gedemonstreerd met behulp van de taal, die ook volgens Fichte de ziel van de natie belichaamt. Deze volken spreken immers niet langer hun oorspronkelijke taal, die namelijk met vreemde invloeden is vermengd of hierdoor zelfs geheel is overwoekerd. Maar tegenover dood en ontbinding staat ook bij Fichte het leven, dat zijn hoogste uitdrukking vindt in de Duitse Geist. Het Duitse volk is het Urvolk en spreekt dan ook nog een Ursprache, die een afspiegeling is van "die reinmenschliche Sprache". De Duitse natie laat zich slechts vergelijken met het klassieke Griekenland: zij is "die Sonne im Mittelpunkt der Welt"; het zuivere centrum in een onttakelde wereld, vanwaaruit de wedergeboorte van de mensheid zal worden voorbereid. Daartoe dient zij uiteraard wel te worden behoed voor vreemde invloeden en vermengingen met andere volken. In zijn Reden ontwerpt Fichte dan ook een streng, ascetisch opvoedingsmodel, waarbij de kinderen via nationale opvoedingsinstituten worden voorbereid op een samenleving, die een hermetisch gesloten geheel zal vormen. En zoals hij opmerkt:

"Ein solches (Ganze-A.L.) kann kein Volk anderer Abkunft und

Sprache in sich aufnehmen und mit sich vermischen wollen, ohne

${ }^{30}$ F. Schiller, Werke Bd. 1-2 (Wiesbaden z.j.; hrsg. von P. Stapf) Bd. 2, p. 256 (het gedicht Deutsche Grósse); Novalis, Die Christenheit oder Europa, in: Werke in einem Band (München/Wien 1981), p. 538-539. 
wenigstens fürs erste sich zu verwirren, und den gleichmäßigen Fortgang seiner Bildung mächtig zu störea. ${ }^{n 31}$

Soortgelijke geluiden beluistert men bij Ernst Moritz Arndt, bij wie nationalisme soms uitmondt in onverholen racisme. Meer nog dan voor Fichte is zuiverheid voor Arndt een regelrechte obsessie. Bij herhaling beklaagt hij zich over:

"ungebührliche und verderbliche Vermischung der Völker miteinander, die Zusammenmischung zuvieler fremdartigen Bestandteile, kurz, was wir mit einem ausdrucksvollen Worte die Verbastardung der Volker nennen.. ${ }^{\text {32 }}$

De wereld van flora en fauna wordt aangeroepen als bewijs voor de verderfelijke werking van "hurischer Paarungen", die slechts ziekelijke en -in het geval van dieren- ontrouwe, slaafse, instinctloze types voortbrengen. Ook de geschiedenis levert de nodige leerrijke voorbeelden. De bloei van het oude Hellas wordt verklaard door een eugenetische politiek, waarbij vooral werd gelet "auf reines und gleiches Blut". Het verval kwam met de komst van vreemden, zoals vervolgens ook Rome, Constantinopel en het eigentijdse Frankrijk werden "vergiftet" en door vermenging tenonder gingen. Het vermengde volk is namelijk onrustig, wild en onmatig, hetgeen duidt op "eine ursprüngliche Zerrütung der Triebe". Voor de Duitsers gloort daarentegen nog hoop, want:

"..sie sind keine Mischlinge geworden, sie sind mehr als viele andere Völker in ihrer angebornen Reinheit geblieben und haben sich aus dieser Reinheit ibrer Art und Natur nach den stetigen Gesetzen der Zeit langsam und still entwickeln kōnnen.. ${ }^{{ }^{33}}$

Ook Arndt beschouwt de Duitsers als moderne Grieken; als een Urvolk, dat zich van vreemde smetten moet zuiveren. Vergeleken met de filosofische distantie van Fichte is zijn toon echter rauw. Arndt predikt de openlijke haat tussen volkeren. Die xenofobie richt zich uiteraard vooral tegen de Fransen, die het Duitse volk "ver-

31 J.G. Fichte, Reden an die deutsche Nation (Hamburg 1978), p. 207. Vgl. ibid., p. 26, 60 e.v., 207, 211, 233 en 243 e.v.

32 E.M. Arndt, Volk und Staat. Schriften in Auswahl. (Leipzig 1934; hrsg. von P. Requadt), p. 81.

${ }^{33}$ Ibid., p. 92. Vgl. ibid., p. 82-87 en 91. 
weichlichen und entnerven". Hier lijkt bijna sprake van een complot, dat zich Duitsland's Entartung tot doel zou hebben gesteld; een gevaar, dat door hem wordt geassocieerd met vervreemding, chaos, ziekte, psychische zwakte en vrouwelijkheid. Het Duitse ideaal is daarentegen "nichts als Freiheit Männlichkeit Keuschheit Ordnung und Zucht". En dat -ascetische- ideaal wordt zijns inziens ook van binnenuit bedreigd door vreemde elementen, die zich in de schoot van de Duitse natie zouden hebben genesteld. Op dit punt krijgt Arndt's paranoia racistische trekken, aangezien zijn woede zich vooral richt tegen de "allweltliche Judensinn". De jood wordt bij hem het symbool voor kosmopolitisme, humaniteit en ontworteling; hij vertegenwoordigt de chaos en het verval, die het Duitse karakter ondergraven. ${ }^{34}$

Bij Fichte en Arndt wordt het verlangen naar zuiverheid verbonden met de angst voor degeneratie; een combinatie die men vanaf nu ook bij anderen telkens opnieuw kan waarnemen. Ziekte, dood en ontbinding zijn symbolen van de chaos, die men om zich heen en in zichzelf bespeurt, en die wordt begeleid door een gevoel van onreinheid, waarvan men zich tracht te zuiveren. Dit verlangen naar zuiverheid wordt verbonden met de piëtistische hoop op Wedergeboorte, die nu in een geseculariseerde vorm wordt geprojecteerd op de natie. In een tijd van ingrijpende veranderingen dekt de natie de psychologische behoefte aan een vaste orde en geborgenheid. De natie is de uitgebreide Mannerbund, gebaseerd op vriendschap en genegenheid, of wordt voorgesteld als een moederlijke vrouw, die zoals de Pruisische koningin Luise als een moderne madonna wordt vereerd. $\mathrm{Zij}$ is, zoals Zacharias Werner haar in 1810 bezingt, "wie den Reinen":

"So rein, so schön, so milde,

${ }^{34}$ Vgl. ibid., p. 160. Zie ook: H. Kohn, Wege und Irwege. Vom Geist des deutschen Bürgertums. (Düsseldorf 1962), p. 82; Chr. Prignitz, Vaterlandsliebe und Freiheit. Deutscher Patriotismus von 1750 bis 1850. (Wiesbaden 1981), p. 134. 
Spiegel vom ew'gen Licht! "35

Die psychologische behoefte is ook zeker aanwijsbaar bij Fichte en Arndt. Beiden zijn afkomstig uit de lagere standen en hebben zich via een lange en harde weg moeten opwerken op de sociale ladder. Beiden verraden in hun houding dan ook een fundamentele onzekerheid over hun sociale positie, die zich bevindt in het spanningsveld tussen de wereld van de geletterde burgerij en die van de lagere standen, die zij nu idealiseren. De ware natie wordt immers gedragen door het mythische Volk, dat oorspronkelijk en dus zuiver is, en dat de belichaming vormt van de regressieve hoop op terugkeer naar een staat van verloren onschuld. Fichte en Arndt staan zo aan de wieg van de volkische beweging, die ook in haar verdere ontwikkeling zal worden getekend door mixofobie en racistische sentimenten. ${ }^{36}$

De angst voor verandering en ambiguïteit en het daaruit voortvloeiende gebod tot zuiverheid tonen zich het scherpst, waar de idee van de natie wordt ondersteund door -of overgaat in- de voorstelling van het ras, dat immers slechts door sexuele hygiëne voor ongewenste vermengingen kan worden behoed. Het verlangen naar zuiverheid behoort dan ook, aldus Taguieff, tot de kern van het racisme. Dergelijke raciale opvattingen lijken zich vanaf het einde van de achttiende eeuw te verdichten tot een hechte doctrine. In Duitsland behoort de filosoof Kant tot de eersten, die zich -onder meer in Von den verschiedenen Racen der Menschen uit 1775 en zijn Bestimmung des Begriffs einer Menschenrace van 1785- intensief met het rassenvraagstuk hebben bezig gehouden. De schrijver

35 Geciteerd bij W. Wülfing/K. Bruns/R. Parr, Historische Mythologie der Deutschen, 1798-1918 (München 1991), p. 85. Vgl. G. Mosse, Nationalism and sexuality. Respectability and abnormal sexuality in modern Europe. (New York 1985), p. 7, 18, 30-31 en 78. Over de relatie tussen piëtisme en nationalisme: vgl. K.S. Pinson, Pietism as a factor in the rise of German nationalism (New York 1968; 2e druk) en G. Kaiser, Pietismus und Patriotismus im literarischen Deutschland. Ein Beitrag zum Problem der Säkularisation. (Wiesbaden 1961).

${ }^{36}$ Vgl. E.N. Anderson, Nationalism and the cultural crisis in Prussia, 1806-1815 (New York 1939), hoofdstuk 2 en 3. 
van de Kritik der reinen Vernunft getuigt ook op dit terrein van zijn onbedwingbare behoefte aan orde en classificatie. Bij Kant wordt het ras tot een natuurlijke en daarom onveranderlijke grootheid, die op grond van erfelijke eigenschappen wordt bepaald en waarin klimaat en milieu slechts een secundaire rol vervullen. Op basis van uiterlijke kentekenen, en in het bijzonder de huidskleur, wordt de mensheid in vier rassen verdeeld, die niet mogen worden vermengd. Het uiterlijk weerspiegelt evenwel het innerlijk. Daarbij bestaat geen twijfel over de superioriteit der blanken, die "zu allen Zeiten die andern belehrt und durch die Waffen bezwungen" hebben. Daartegenover staan dan de negers, aan wie hij een bijna dierlijke status toekent en wier lichaamsgeur hij, met dat voor de moderne burger zo opmerkelijke reukvermogen, vanuit Königsberg meent op te snuiven. Negers stinken en geven daarmee zoals vervolgens ook de joden en de armen in de steden- blijk van hun losbandig, dierlijk gedrag, dat wordt geleid door de lagere instincten en dat, indien niet gecontroleerd, slechts tot chaos en anarchie kan leiden. ${ }^{37}$

Blond haar en blauwe ogen vormen daartegenover een esthetische norm, die samenvalt met de burgerlijke moraal van orde en fatsoen. Die eigenschappen worden geassocieerd met het ideaal van Winckelmann, dat vrijwel direct in de nieuwe rassentheorieën wordt geïncorporeerd. Dat is het geval bij de Göttinger geschiedfilosoof Christoph Meiners, die in zijn Grundriß der Geschichte der Menschheit van 1785 een scherp onderscheid maakt tussen een "licht en mooi" en een "donker en lelijk" ras, waarbij het eerste uiteraard superieur is. Evenzo verdeelt de geneeskundige Carl Gustav Carus in zijn System der Physiologie van 1838 de mensheid in dag- en nachtvolken. De gehele culturele ontwikkeling van de mensheid beweegt zich tussen de polen zwart en wit, culminerend

37 Geciteerd bij: W. Conze, Rasse, in: W. Conze/O. Brunner/R. Koselleck (Hrsg.), Geschichtliche Grundbegriffe. Historisches Lexikon zur politisch-sozialen Sprache in Deutschland. Bd. 5 (Stuttgart 1984), p. 148. Vgl. P.-A. Taguieff, o.c., p. 149; G.L. Mosse, Toward the final solution. A history of European racism. (London/Melbourne/Toronto 1978), p. xvi, 1 en 30-31; L. Poliakov, o.c., p. 173-174; M. Onfray, o.c., p. 96 e.v. en 116 e.v. 
bij de ware Tagvolker -de Duitsers, Engelsen en Fransen-, die "als eigentliche Blüte der Menschheit" moeten worden beschouwd. ${ }^{38}$

Hoewel de kring van uitverkoren volken onder invloed van nationale vooroordelen steeds kleiner wordt en zich uiteindelijk beperkt tot Duitsland zelf, blijven licht en donker geliefde metaforen, op grond waarvan een dichotoom beeld van de mensheid kan worden geconstrueerd. Die classificaties worden rond het midden van de negentiende eeuw in toenemende mate verbonden met de arische mythe, die in Duitsland voor het eerst gestalte krijgt in Friedrich Schlegel's Uber die Sprache und Weisheit der Inder van 1808. Met behulp van -opnieuw- linguïstische argumenten wordt getracht om de verwantschap te tonen tussen de moderne Duitsers, de Grieken en het legendarische volk der Aryas, die zich vanuit India over Europa zouden hebben verbreid. De arische mythe is de mythe van de zuivere oorsprong, die getuigt van het regressieve verlangen naar de "gouden tijd". De Aryas vertegenwoordigen het eigen ideaalbeeld: zij zijn het jongste volk, dat heerst zonder heerszuchtig te zijn en dat standvastig is; een volk van boeren, dat geworteld is in Moeder Aarde zelf. Daarmee verbonden is een groeiende aversie van joden, die nu in toenemende mate worden gezien als het symbool van moderniteit en daarmee als de ware tegenstanders in de manicheïsche strijd om een zuiver bestaan. ${ }^{39}$

Schopenhauer's filosofie is een van de belangrijkste kanalen, waarlangs dergelijke ideeën zich hebben verbreid. Zijn liefde voor dieren wordt slechts geëvenaard door zijn afkeer van de Foetor Judalcus, die hij tot in de verste uithoeken van de christelijke beschaving bespeurt. De Jahweh van het Oude Testament heeft de wereld uit het niets geschapen en laat zo geen ruimte voor het geloof in metempsychose, dat volgens de misantroop ten grondslag ligt aan alle dierenliefde. Wreedheden tegenover dieren zoals

${ }^{38}$ Geciteerd bij: W. Conze, o.c., p. 154. Vgl. ibid., p. 150 e.v.; G.L. Mosse, Final solution, p. xii, 10 e.v., 21 e.v. en 33 e.v.; L. Poliakov, o.c., p. 180 e.v. en 256.

$39 \mathrm{Vgl}$. G.L. Mosse, Final solution, p. 40 e.v.; L. Poliakov, o.c., p. 193 e.v.; H.W. von der Dunk, Voorbij de verboden drempel. De Shoah in ons geschiedbeeld. (Amsterdam 1990), p. 82 e.v. 
vivisectie, onbarmhartige slachtpraktijken en overmatige vleesconsumptie kunnen zo tot hun joodse wortels worden getraceerd. Daarbij is men ongelukkigerwijze vergeten, dat het ware christendom niet van joodse, maar van Indische origine is. Schopenhauer spant zich dan ook in om aan te tonen, dat het Nieuwe Testament op essentiële punten overeenstemt met de geloofswereld van het Boeddhisme en het Hindoeiisme, zoals hij vervolgens ook tracht om de Germaanse mythologie met die van het oude India te verbinden. Daarmee ontstaat een merkwaardige combinatie van Indomanie, antisemitisme, anti-vivisectionisme en vegetarisme, die via Schopenhauer's leerling, Richard Wagner, in bredere kring zal doordringen. ${ }^{40}$

\section{Der Fall Wagner}

Bij Wagner komen inderdaad vele lijnen samen, terwijl zijn invloed op navolgende generaties moeilijk kan worden overschat. Zijn wereldbeschouwing verbindt het neo-humanistische Bildungsidealismus met de piëtistische hoop op Wedergeboorte, die deel uitmaakt van een arisch, Duits-nationaal heilsplan en afhankelijk is van een puriteinse leefwijze, waarin rassenhygiëne, kuisheid, vegetarisme en anti-vivisectionisme een belangrijke rol spelen. Deze wereldbeschouwing wordt gedragen door het ideaal van das Reinmenschliche: het ideaal van de esthetische mens, die van de arbeid en de zorg om het bestaan is bevrijd en van alle politieke en maatschappelijke beperkingen is ontdaan. Wagner verwijst daarmee impliciet naar Schiller's Briefe uber die asthetische Erziehung des Menschen uit 1795. En zoals Schiller hanteert ook hij een geschiedfilosofisch schema, dat formele gelijkenis vertoont met het christelijke heilsplan. Het begin van de geschiedenis wordt gevormd door de zuivere esthetische mens, die in harmonie leeft met de natuur,

$40 \mathrm{Vgl}$. A. Schopenhauer, Über die Grundlage der Moral, in: idem, Zurcher Ausgabe. Werke Bd. 1-11 (Zürich 1977) Bd. 6, p. 278-279 (par. 19); idem, Fragmente zur Geschichte der Philosophie, in: o.c. Bd. 7, p. 87 (par. 12); idem, Über Religion, in: o.c. Bd. 10, p. 403, 408-415 en 443 (par. 177 en 190). Zie ook: L. Poliakov, o.c., p. 253 e.v.; M. Onfray, o.c., p. 125126. 
zichzelf en zijn medemensen. Dat ideaal van de "gouden tijd" wordt ook door Wagner verbonden met de aan de Duitsers verwante Grieken, die "das reine Ideal menschlicher Schönheit" vertegenwoordigen. Bij hen waren religie, staat en kunst nog eén; de kunstenaar was nog een deel van het volk, dat in zijn werk participeerde en hierin zijn hoogste uitdrukking vond. Die alles overheersende harmonie wordt in de kunst vooral gereflecteerd door de tragedie, waarin alle disciplines die later zouden worden gescheiden -drama, dans, poëzie en muziek- tot een hogere eenheid waren versmolten. Voor de modernen, die in een onttakelde wereld leven, vormen de Grieken zo het ideaal, dat zij op eigen voorwaarden moeten trachten te realiseren. ${ }^{41}$

De idee van das Reinmenschliche ontleent haar betekenis vooral aan het contrast met deze moderne wereld, die het product is van een ware zondeval. Wagner's houding tegenover de burgerlijke samenleving wordt het meest pregnant uitgedrukt in een brief uit 1851:

"Meine ganze Politik ist nichts weiter mehr als der blutigste $\mathrm{HaB}$ unserer ganzen Zivilisation. ${ }^{42}$

Die haat richt zich in de eerste plaats op de wereld van de kunst, die volgens Wagner wordt gekenmerkt door oppervlakkigheid, effectbejag, commercie en nepotisme. Het verval der kunsten maakt echter deel uit van een meer omvattend proces van degeneratie; de moderne beschaving is zelf onesthetisch en heeft "diesen heutigen europäischen Menschen kunstunfähig gemacht." Bij herhaling keert Wagner zich tegen het egoïsme, de zinnelijkheid (Genußsinnlichkeit) en het utilitarisme, die het leven in de burgerlijke samenleving bepalen. Esthetische kritiek gaat zo over in sociale kritiek, die zich voorts richt tegen kapitalisme, mechanisering en vooral tegen de

41 R. Wagner, Die Hauptschrifien (Stuttgart 1956; hrsg. von E. Bücken), p. 240. Vgl. ibid., p. 108 e.v. en 402. Zie ook: W. Schüler, Der Bayreuther Kreis von seiner Entstehung bis zum Ausgang der Wilhelminischen Ära. Wagnerkult und Kulturreform im Geiste völkischer Weltanschauung. (Münster 1971), p. 12 e.v.

${ }^{42}$ R. Wagner aan E.B. Kietz, 30-12-1851, geciteerd bij: W. Schüler, o.c., p. 16. Vgl. R. Wagner, o.c., p. 112. 
macht van het geld, dat het symbool is van alle moderne kwalen. De wereld van het geld is de wereld van Schopenhauer's Wil, waarin ieder de ander een wolf is. In die wereld wordt de kunstenaar tot het eenzame genie, dat zijn natuurlijke binding met het Volk, zijn ware publiek, dreigt te verliezen. Temidden van de moderne chaos blijft het beeld van das Reinmenschliche alleen in de kunst bewaard. De kunstenaar is niets anders dan "die Kraft der rein menschlichen Individualität überhaupt"; een heilige bijna die, gedragen door "die Überzeugung von seiner reinsten Keuschheit", de tragische opdracht heeft om het verloren ideaal te herstellen. ${ }^{43}$

Vanuit de diepten van de moderne samenleving verheft Wagner de roep om een algehele revolutie, die hij later -in een poging om zijn politieke optreden van 1848 te vergeten- bij voorkeur aanduidt als Wiedergeburt of Regeneration. De revolutie wordt bezongen als "Erlöserin aus dieser Welt des Jammers" en als "die Schöpferin einer neuen, für alle beglückende Welt". Daarbij zal de wedergeboorte van de kunst een onderdeel moeten zijn van een omvattende maatschappelijke regeneratie, die op haar beurt door de kunst moet worden geleid. Kunst en sociale revolutie volgen hetzelfde doel:

"Dieses Ziel ist der starke und schöne Mensch: die Revolution gebe

ihm die Stärke, die Kunst die Schōnheit! -

De beoogde maatschappelijke regeneratie zal uitmonden in een hechte gemeenschap, waarin de arbeid niet langer uit nood of omwille van het geld zal worden verricht, maar genoegen zal bereiden. Deze asthetische Staat berust op das Reinmenschliche en zo op de natuur zelf, die alle politieke, sociale en religieuze scheidslijnen uitwist. Zij wordt gesmeed door banden van liefde; de liefde, die volgens Wagner de kern vormt van das Reinmenschliche en de enige weg tot Verlossing is. Deze gemeenschap zal opnieuw zoals in de Griekse oudheid-worden gedragen door het Volk en zal haar hoogste uitdrukking vinden in de regeneratie van de kunst en wel in het Gesamtkunstwerk, dat de herwonnen totaliteit op symbo-

${ }^{43}$ R. Wagner, o.c., p. 44 en 128 . Vgl. ibid., p. 108 e.v., 116 e.v., 191 en 272; W. Schüler, o.c., p. 16.

${ }^{44}$ R. Wagner, o.c., p. 114. Vgl. ibid., p. 77-78. 
lische wijze gestalte geeft. Het kunstwerk van de toekomst is niet langer de schepping van het eenzame genie, maar "ein gemeinsames" dat "aus einem gemeinsamen Verlangen" wordt geboren. ${ }^{\text {ss }}$

Wagner's Weltanschauung is een wereldlijke religie, waarin de kunst tot heilmiddel is verheven. Hij verkondigt "die neue Religion", die hij aanvankelijk scherp afzet tegen het christendom. Het christendom predikt namelijk een onbereikbaar, zuiver geestelijk ideaal en ontkent daarmee de zinnelijke zijde van het bestaan. De kunst verbindt juist het geestelijke en het zinnelijke; zij toont de Idee in een concrete, tastbare vorm. En dat geldt met name voor de muziek, waarin deze Idee zich op directe wijze uitspreekt; "durch das reinigende Feuer der musikalischen Idealität" wordt de toehoorder de toegang geopend tot een hogere wereld. In navolging van Schopenhauer ziet Wagner de kunstenaar zo als een middelaar, die de mensheid de weg naar Verlossing wijst. De ware kunstenaar wordt -zoals Beethoven- gekenmerkt door zijn "männliche Kraft" en zijn strenge religieuze en burgerlijke moraal. Hij weerstaat de verleidingen van de wereld en de "verweichlichte" smaak van het publiek. Hij is het eenzame genie, wiens hoge ideaal telkens opnieuw door de realiteit wordt weersproken en die zo het lijden van de mensheid op zich neemt. ${ }^{46}$

Deze karakteristiek, Wagner's gestileerde zelfbeeld, vertoont opvallend sterke ascetische trekken. Zijn denken blijft dan ook in hoge mate gebonden aan christelijke voorstellingen, die mettertijd zelfs aan kracht winnen. De kritiek, die hij aanvankelijk op het christendom uit, blijft in feite halfslachtig. Ook hij vertoont een hevige aversie van zinnelijkheid en materialisme, die hij als de hoofdzonden van de moderne beschaving brandmerkt. Het zinnelijke wordt slechts aanvaard, voorzover geheiligd door de kunst, die een stoffelijk omhulsel behoeft, waarin de spirituele Idee eerst gestalte kan aannemen. Hoewel de grenslijnen tussen het geestelijke en het zinnelijke zijn verlegd, blijft de dichotomie van het christendom zo in essentie gehandhaafd. Wagner volgt daarmee de traditie

\footnotetext{
${ }^{45}$ Ibid., p. 123. Vgl. ibid., p. 58, 64, 111-113, 116, 125-126 en 227.

${ }^{46}$ Ibid., p. 82, 123, 265, 272-273, 281, 291, 294-295 en 408.
} 
van het Idealisme: de materie is de vormeloze chaos, die wordt geassocieerd met het vrouwelijke en die moet worden bezield door de mannelijke Formtrieb van de geest, die haar het stempel van de Idee opdrukt. De Idee is daarbij de expressie van Schopenhauer's Wil; zij vertegenwoordigt het inzicht in de fundamentele disharmonie van het bestaan. De ware religiositeit vereist dan ook "Verneinung der Welt", "Entsagung und freiwilliges Leiden", waarmee men het egoïsme praktisch ontkent en "das unermeßlich erhabene Wonnegefühl der Weltüberwindung" deelachtig wordt. De ware kunstenaar beschikt over de hiertoe vereiste bovenmenselijke kracht; hij offert zichzelf en neemt alle lijden op zich, inzoverre hij de tragische grond van het bestaan doorschouwt en dit inzicht in een dragelijke vorm presenteert, waardoor zijn toehoorders worden gelouterd. En juist in deze hoogste vorm van lijden manifesteert zich zijn verlangen naar zuiverheid, want hij wordt -zoals Wagner over zichzelf opmerkt-beheerst door:

"Sehnsucht nach Befriedigung in einem höheren, edleren Elemente, das, in seinem Gegensatze zu der einzig unmittelbar erkennbaren GenuBsinnlichkeit der mich umgebenden modernen Gegenwart in Leben und Kunst, mir als ein reines, keusches, jungfräuliches, unnahbar und ungreifbar liebendes erscheinen mußte. ${ }^{n 47}$

Hoewel Wagner's wereldbeschouwing de invloed verraadt van het Duitse Idealisme, zijn er toch ook belangrijke verschillen. De kloof, die hem van zijn voorgangers scheidt, wordt pas ten volle zichtbaar, waar zijn pleidooi voor spirituele regeneratie overgaat in de oproep tot nationale en raciale zuiverheid. De culturele decadentie, die hij om zich heen waarneemt, is zijns inziens immers onlosmakelijk verbonden met fysieke en biologische degeneratie. Dat verband wordt reeds zichtbaar in zijn essay Das Judentum in der Musik uit 1850, waar de jood wordt ontmaskerd als de diabolische oorsprong van alle moderne kwaden. De jood is de vreemdeling;

47 Ibid., p. 58. Vgl. ibid., p. 232 en 265 e.v. Over de relatie tussen esthetische en sexuele classificaties in het Idealisme: zie F. Schiller, Briefe über die ästhetische Erziehung des Menschen, in: idem, o.c. Bd. 2, m.n. brieven 11, 12 en 13; W. von Humboldt, Gesammelte Schriften Bd. 1, m.n. p. 319-322, 350-352 en 362-363. 
een indringer in een cultuur, waaraan hij innerlijk geen deel heeft. $\mathrm{Hij}$ is een toneelspeler, die zijn omgeving omtrent zijn ware identiteit misleidt. Bovenal echter is hij het symbool van de moderne chaos, die wordt geassocieerd met het altijd beweeglijke geld..$^{48}$

Mede onder invloed van Gobineau worden dergelijke ideeën in latere jaren uitgewerkt tot een omvattende leer, waarin het ras wordt verheven tot de centrale categorie in de wereldgeschiedenis. Met name het essay Heldentum und Christentum uit 1881 vormt een curieuze mengeling van verlangen naar spirituele zuiverheid, ascetisme en mixofobie. De degeneratie van de moderne beschaving wordt hier verklaard vanuit het arische bloed, dat niet alleen is verdorven door de consumptie van vlees, maar vooral door de vermenging met lagere rassen. Het superieure arische ras was vrij en waarachtig, en bovenal in staat tot het bewuste lijden, dat volgens Wagner het ware kenteken van humaniteit is. De overige rassen geven zich daarentegen over aan hun zinnelijke lusten en kunnen hun dierlijke afkomst nauwelijks verhullen. Te gering in aantal moesten de ariërs zich met hen vermengen, waarbij zij "durch den Verlust ihrer Reinheit" meer verloren dan de anderen door "die Veredlung ihres Blutes" wonnen. Met name de vermenging met semitisch bloed leidde tot het verval van de arische beschaving, dat volgens Wagner slechts door een hersteld geloof in Christus kan worden geremd. Wagner's Christus is daarbij de arische Christus van Paul de Lagarde: de zuiverste mens, die in een tijd van vergaande rasvermenging werd geboren en wel op de plaats, die het centrum vormde van alle onreinheid. Hij is de hoogste manifestatie van Schopenhauer's Wil, die in hem Verlossing zoekt. Hij nam het universele lijden op zich en vergoot zijn bloed, opdat het door zijn spirituele zuiverheid de mensheid zou reinigen van alle zonden, die het gevolg waren van ongeoorloofde vermengingen. Zoals Wagner opmerkt:

"Während wir somit das Blut edelster Rassen durch Vermischung sich verderben sehen, dürfte den niedrigsten Rassen der Genuß des Blutes Jesu, wie er in dem einzigen echten Sakramente der christli-

48 Vgl. R. Wagner, Sämtliche Schriften und Dichtungen. Volks-Ausgabe Bd. 5 (Leipzig z.j.; 6e druk), m.n. p. 70-71, 73, 78, 81-82 en 84-85. 
chen Religion symbolisch vor sich geht, zu göttlichster Reinigung gedeihen. ${ }^{n 49}$

Spirituele regeneratie is volgens Wagner de laatst mogelijke remedie tegen het biologische verval. Daarbij laat hij er geen twijfel over bestaan, dat zijn hoop vooral gevestigd is op de ware erfgenamen van de ariêrs: de Duitsers. Zijn "neue Religion" is een "Duits geloof": een van joodse smetten gezuiverd christendom, dat wordt omkleed met de germaanse mythologie. Zijn ideaal is de arische Verlosser: Parsifal, die de "Erlösung des Erlösers" bewerkstelligt, waardoor Christus van zijn joodse oorsprong wordt bevrijd. Het is deze nationale religie, die in het door Wagner opgerichte theater te Bayreuth voor duizenden bewonderende Bildungsburger zal worden uitgedragen. . $^{\text {so }}$

Het geval Wagner kan inzicht verschaffen in de psychobiografische achtergrond van het verlangen naar zuiverheid, dat zijn wereldbeschouwing zozeer beheerst. Van belang lijkt daarbij vooral zijn onzekerheid omtrent zijn afkomst. Was hij de zoon van Karl Wagner of van de acteur Ludwig Geyer, met wie zijn moeder al spoedig na de dood van haar eerste echtgenoot hertrouwde? En was deze Geyer, zoals Wagner vermoedde, van joodse afkomst? Wagner lijkt inderdaad te hebben geloofd, dat hij de "bastaard" was van een ongeoorloofde "vermenging" en zo de zoon van de "joodse" Geyer. ${ }^{51}$ Zijn antisemitisme lijkt zijn oorsprong te vinden in een

49 R. Wagner, Hauptschriften, p. 422 . Vgl. ibid., m.n. p. 415 en 419. Zie voorts: G. Mann, Rassenhygiene-Sozialdarwinismus, in: G. Mann (Hrsg.), Biologismus im 19. Jahrhundert (Stuttgart 1973), p. 74 e.v.; W. Schüler, o.c., p. 187 en 235 e.v.

${ }^{50} \mathrm{Vgl}$. R. Wagner, Hauptschriften, p. 234-237, 251, 341 en 419. Zie voorts: W. Schüler, o.c., p. 222; M. Verhoeve, Wagner en de redding van het Duitse volk. Het "Reinmenschliche" in het werk van een Duitse componist, in: Skript jrg. 12, nr. 2 (1990), p. 169; H. Zelinsky, Die Feuerkur, in: Musik-Konzepte 5 (juli 1978), p. 84.

$51 \mathrm{Vgl}$. L. Poliakov, Histoire de l'antisémitisme. Tome 2: L'âge de la science. (Paris 1981), p. 237-238. Wagner deelt die onzekerheid met andere antisemieten zoals Wilhelm Marr, Richard Heydrich en Hitler: vgl. S. Friedländer, L'antisémitisme Nazi. Histoire d'un psychose collective. (Paris 
verstoorde relatie met zijn vader, met wie hij zich moeilijk kon identificeren. De jood, die hij bestrijdt, is Geyer: een indringer en een toneelspeler, die anderen omtrent zijn ware identiteit misleidt. $\mathrm{Hij}$ is de vader, die Wagner anvankelijk ook zoekt in de later zo gehate Meyerbeer; de vader, die wordt geassocieerd met de God van het Oude Testament, die Wagner afwijst om zich te identificeren met de Zoon. ${ }^{52}$ Dat de jood tegelijk wordt geassocieerd met het vrouwelijke, is daarmee niet in tegenspraak. De vrouw is een symbool voor de oergrond van het leven, waar alle grenzen dreigen te vervloeien. De heldere orde, die door de mannelijke Formtrieb wordt gecreëerd, wordt door de vrouw -en haar sexualiteit- bedreigd. De associatie met het vrouwelijke onderstreept slechts Wagner's onzekerheid over de identiteit van de jood en van Geyer in het bijzonder. Tegelijk legitimeert deze associatie zijn verzet. De man met vrouwelijke eigenschappen is immers gedegenereerd en verdient geen respect. De verbinding tussen de jood en het vrouwelijke rechtvaardigt Wagner's opstand en ontlast hem van zijn schuldgevoelens.

Die schuldgevoelens laten zich echter niet onderdrukken en uiten zich vooral in Wagner's gespannen verhouding ten opzichte van lichaam en sexualiteit. Zijn verlangen naar een "gouden tijd" en zijn hoop op Wedergeboorte hebben onmiskenbaar een regressief karakter. De liefde die hiertoe leidt, is asexueel en wordt gesymboliseerd door kuise vrouwen, die zich vrijwillig voor de man opofferen: Senta in Der fliegende Hollander en Elisabeth, die door haar dood Tannhäuser uit de "Wollusthöhlen des Venusberges" redt. $^{53}$ Niet minder kuis zijn de helden, zoals in Lohengrin en Parsifal. Parsifal weerstaat de verleidingen van Kundry, die het symbool is van vrouwelijke wellust en wordt geassocieerd met de jood. ${ }^{54} \mathrm{Zij}$ wordt door hem gedoopt en zo bevrijd van kwaad en zinnelijkheid,

1971), p. 133 e.v.

${ }^{52} \mathrm{Vgl}$. L. Poliakov, Histoire de l'antisémitisme, p. 240-241.

53 Geciteerd bij: W. Schüler, o.c., p. 21. Vgl. G.L. Mosse, Final solution, p. 103-104.

${ }^{54}$ Vgl. M. Verhoeve, o.c., p. 169. 
maar tegelijk -op een ander niveau- van haar joodszijn. Sexualiteit verschijnt bij Wagner als een gevaar voor de ware identiteit, die zoals Parsifal- zuiver is en die door Kundry -zoals door Geyerwordt bedreigd.

Wagner's associaties vertonen een dieper patroon. De jood wordt verbonden met wellust en sexualiteit; hij vertegenwoordigt de chaos en is daarom onrein. De chaos die Wagner om zich heen waarneemt, vindt echter zijn oorsprong in hemzelf. De instabiliteit van zijn karakter wordt rijk gedocumenteerd door zijn agressie, haat, woedeaanvallen en dromen van vernietiging, door zijn zwaarmoedige buien en zijn obsessie met ziekte en dood. Zijn karakter wordt bepaald door de anarchie van gevoelens, die duidt op een conflictueuze identiteit. De strijd tegen joden en zinnelijkheid is zo tegelijk een innerlijke strijd tegen het "valse Ik", dat moet worden uitgedreven, opdat het "ware Ik" zegeviert. De jood, die Wagner zo sterk afwijst, is tegelijk de jood, met wie hij zich identificeert en die hij in zichzelf vermoedt. ${ }^{55}$ De strijd tegen deze innerlijke vijand vereist een voortdurende purificatie via niet aflatende ascese en onthouding. Wagner lijkt te beantwoorden aan het type van de melancholicus, die zichzelf moet offeren als straf voor niet toegestane verlangens en verboden gevoelens van agressie, die zich in zijn geval oorspronkelijk richtten tegen Geyer. De straf bestaat daarbij in het schuldbesef zelf, dat zo in eerste instantie naar binnen wordt gericht. In die situatie ontstaat dan de behoefte aan een surrogaatslachtoffer, waarop het gevoel van agressie kan worden afgeleid. De innerlijke strijd om een stabiele identiteit wordt geprojecteerd op de raszuivere natie, die van vreemde elementen moet worden ontdaan. De mislukte identificatie met de vader vormt zo de oorsprong van een pathologische smetvrees, die op alle terreinen -van zijn verheven Idealisme tot zijn fanatieke racisme- tot uitdrukking komt. ${ }^{56}$

55 Vgl. L. Poliakov, Histoire de l'antisémitisme, p. 255-257.

56 Voor een nadere bespreking van de samenhang tussen melancholie en smetvrees: vgl. E. Pewzner, o.c., hoofdstukken 3 en 4. 
Zuiverheid en de Kultur- und Lebensreformbewegung

Het geval Wagner staat niet op zichzelf. Soortgelijke voorstellingen keren op een bredere schaal terug binnen de Kultur- und Lebensreformbewegung, die met name rond de eeuwwende snel aan kracht wint. Het betreft hier een "bürgerliche Revolte", die haar aanhang vooral vindt binnen die kringen van het Bildungsburgertum die zich door de snelle maatschappelijke veranderingen van het Tweede Keizerrijk in hun positie bedreigd voelen. Deze Kultur- und Lebensreformbewegung omvat een grote verscheidenheid van stromingen, variërend van de aanhangers van Lebensphilosophie en theosofie tot de pleitbezorgers van natuurgeneeswijze, geheelonthouding, vegetarisme, anti-vivisectionisme, tuinsteden, rassenhygiëne, naturisme en jeugdcultuur. Wat al deze groepen verbindt is het verlangen naar zuiverheid. ${ }^{57}$ En ook hier wordt de achtergrond van dat verlangen in hoge mate bepaald door een generatieconflict, dat het burgerlijk gezin in Duitsland met name na 1890 in toenemende mate verscheurt. In de snel veranderende samenleving van het Tweede Keizerrijk vormen de normen en waarden van de vaders niet langer een betrouwbare basis, op grond waarvan de zonen hun weg in de maatschappij kunnen aanvangen. En waar de vaders niet langer als een geschikt identificatiemodel kunnen dienen, verliest ook het in Duitsland relatief sterke patriarchale gezag zijn legitimatie. "Jeugd" is het wachtwoord van de hervormers, die zich keren tegen een verouderde en gedegenereerde samenleving en pleiten voor een culturele en maatschappelijke regeneratie. Het ideaal is een "Rückkehr zur Natur", naar de zuivere oorsprong, die wordt gesitueerd in een mythisch verleden. Hun denken heeft dan ook een cyclisch en regressief karakter; de Kultur- und Lebensreformer zijn revolutionairen, maar "conservatieve revolutionairen",

${ }^{57}$ De enige systematische studie over deze beweging is: W. Krabbe, Gesellschaftsverdnderung durch Lebensreform. Strukturmerkmale einer sozialreformerischen Bewegung im Deutschland der Industrialisierungsperiode. (Göttingen 1974). Het verlangen naar zuiverheid wordt hier echter, als een bindend kenmerk van deze beweging, over het hoofd gezien. 
geleid door de utopie van een traditionele Gemeinschaft die onder moderne voorwaarden moet worden hersteld. ${ }^{s 8}$

De Kultur- und Lebensreformer kiezen voor de daad: hun Idealisme is Tatidealismus. Dit Tatidealismus heeft evenwel een onpolitiek karakter en concentreert zich primair op de verbetering van de mentaliteit en leefwijze van het individu, dat het uitgangspunt vormt voor de beoogde maatschappelijke regeneratie. ${ }^{s 9}$ De Lebensreformer richten zich daarbij vooral op het lichaam en in het bijzonder op de zuiverheid van het bloed, dat wordt bedreigd door verborgen krachten, die het lichaam van buitenaf binnendringen en vergiftigen. Zo schetst de relatief gematigde geheelonthouder Gustav von Bunge in zijn veel gelezen pamfletten, hoe het "gezonde bloed" wordt "vervuild" door de alcohol, die de oorsprong vormt van alle degeneratie: van misdaad, ziekten en krankzinnigheid. ${ }^{60}$ De "Kohlrabiapostel" Adolf Just constateert in zijn populaire boek Kehrt zur Natur zurlick! uit 1896 dezelfde kwalen en wijt deze eveneens aan "unreinen Stoffen im Blute". Volgens hem ligt de voornaamste oorzaak evenwel in de consumptie van vlees, dat de stofwisseling verstoort, het lichaam verwarmt en de zinnen prikkelt, hetgeen

${ }^{58}$ Vgl. U. Linse, Die Jugendkulturbewegung, in: K. Vondung (Hrsg.), Das wilhelminische Bildungsbilrgertum. Zur Sozialgeschichte seiner Ideen. (Göttingen 1975), p. 119-121, 123 en 125; J. Frecot, Die Lebensreformbewegung, in: ibid., p. 138-139 en 145; F. Stern, The politics of cultural despair. A study in the rise of the germanic ideology. (Berkeley/Los Angeles/London 1974; 1e druk 1961), p. xvi e.v.; C. Hepp, Avantgarde. Moderne Kunst, Kulturkritik und Reformbewegungen nach der Jahrhundertwende. (München 1987), p. 75 e.v.; A. Mitzman, Clio's antwoord aan de sfinx: over geschiedenis en psychoanalyse, in: Theoretische Geschiedenis jrg. 14, nr. 1, m.n. p. 26 e.v.

${ }^{59} \mathrm{Vgl}$. W. Krabbe, o.c., p. 15; en J. Frecot, o.c., p. 144.

$60 \mathrm{Vgl}$. G. von Bunge, Alkoholvergiftung und Degeneration (Leipzig 1915; 4e druk), m.n. p. 11-13. Zie ook: idem, Der Vegetarianismus (Basel 1901; 1e druk 1885), p. 27 e.v.; idem, Die Alkoholfrage (Basel 1912; le druk 1886), p. 12 e.v. 
aanleiding geeft tot agressief gedrag en een onnatuurlijke sexuele drang. ${ }^{61}$

Dergelijke geluiden kan men ook vernemen in Richard Ungewitter's Die Nacktheit uit 1907; een boek waarvan circa 100.000 exemplaren werden verkocht. Ungewitter zoekt zijn heil in het naturisme, dat echter ook in zijn geval is verbonden met natuurgeneeswijze, vegetarisme en geheelonthouding. Desalniettemin vormen licht- en luchtbaden zijns inziens de voornaamste remedie tegen de degeneratie van de moderne mens. Naakt is natuurlijk en gezond; kleding is daarentegen het gevolg van culturele dwang en van de valse schaamte voor het lichaam, die ons door het christendom is bijgebracht. Kleding is ongezond, aangezien zij de huid, het grootste menselijke orgaan, belet te ademen. Aldus kunnen de giftige afvalstoffen, die het lichaam uitscheidt, niet worden afgevoerd. Zij dringen het lichaam als "Selbstgifte" opnieuw binnen en leiden zo tot ziekte, nervositeit en soms zelfs de dood. Kleding verbergt het lichaam voor de zon, waardoor de natuurlijke samenstelling van het bloed wordt aangetast. Maar het dragen van kleding heeft ook nadelige gevolgen voor de moraal. Kleren zijn "Kulturlappen", die "jedes Persönlichkeitsgefühl ersticken" en getuigen van een hypocriete mentaliteit. Kleding behoort tot de schijnwereld van het burgerlijk fatsoen; zij vormt de keurige façade, waarachter de naakte persoon zich verbergt. De sexuele fantasie, die door het dragen van kleren zou moeten worden beteugeld, wordt hierdoor in feite juist geprikkeld. Daarentegen is de naakte persoon oprecht en vervuld van een natuurlijke kuisheid. Blootgesteld aan de elementen wordt hij bovendien tot een krachtige, "abgehärtete Natur". Naaktheid draagt zo bij tot de "Züchtung" van een beter ras en wel des te meer, aangezien de natuurlijke schoonheid van het lichaam niet aan het oog wordt onttrokken, zodat de beste partners elkaar kunnen vinden. Bij Ungewitter wordt het naturisme zo geïncorporeerd in de volkische ideologie; naturisme is voor hem een vorm van eugenetica, die is gericht op het herstel van de vroegere Helleense en oud-

61 Vgl. A. Just, Kehrt zur Natur zurück! (Stapelburg-Harz 1900; 4e druk), m.n. p. 15, 100 en passim. Vgl. W. Krabbe, o.c., p. 162; C. Hepp, o.c., p. 75 . 
Germaanse schoonheid en die het Duitse Volk moet sterken tegen verderfelijke orièntaalse en semitische invloeden. ${ }^{62}$

Voor de Lebensreformer bestaat een onverbrekelijk verband tussen lichamelijke reinheid, schoonheid, fysieke en geestelijke gezondheid, en een zuivere en kuise mentaliteit. Hoewel ogenschijnlijk modern in haar verzet tegen de bekrompen burgerlijke moraal, bepleit de beweging in feite een puriteinse en ascetische levenshouding. ${ }^{63}$ Men verlangt weliswaar zinnelijkheid, maar een esthetische, "natuurlijke" vorm van zinnelijkheid, die van elke sexuele betekenis is ontdaan. Opvallend is voorts, dat de roep om een natuurlijke, vrijere leefwijze samengaat met een sterke drang tot controle, die zich uit in de uiterst minutieuze wijze, waarop de vele reinheidsvoorschriften worden beschreven. Die drang naar orde en controle verraadt de diepere betekenis van het verlangen naar zuiverheid. De reiniging van het lichaam is -zoals Mary Douglas reeds opmerkte- niet louter een hygiënische maatregel, maar dient tegelijk ter afbakening van de eigen, onzeker geworden identiteit. Het lichaam is het scherm, waarop dit verlangen wordt geprojecteerd, waarbij men vooral blijk geeft van een opmerkelijke belangstelling voor de openingen en de werking van het darmkanaal. De apostelen van het puriteinse reinheidsgebod zijn juist gefascineerd door het onreine en in het bijzonder door excrementen. De uitscheiding van de onreine elementen vertegenwoordigt voor hen dan ook duidelijk een persoonlijk, existentieel belang, dat door de religieuze toonzetting van hun werk wordt onderstreept. $\mathrm{Zij}$ zijn immers de profeten van een "nieuw geloof", dat in de meest felle bewoordingen tegenover de anderen moet worden verdedigd. Want

${ }^{62}$ Vgl. R. Ungewitter, Die Nacktheit/Nacktheit und Kultur. Zwei Bulcher in einem Band. (Köln-Lövenich 1979; le druk resp. 1907 en 1913), m.n. p. 19, 34, 36 en 41. Vgl. W. Krabbe, o.c., p. 146 e.v. en 162.

${ }^{63}$ Modris Eksteins benadrukt b.v. te eenzijdig de moderne kant van de beweging: vgl. M. Eksteins, Lenteriten. De Eerste Wereldoorlog en het ontstaan van de nieuwe tijd. (Houten 1990), m.n. p. 97 e.v. 
eerst door deze vorm van uitsluiting wordt de cohesie van de eigen groep en daarmee ook de eigen identiteit bevestigd. ${ }^{\text {t4 }}$

Het voorgaande geldt ook voor de Kulturreformer, die zich weliswaar vooral richten op een zuivering van spirituele aard, maar deze toch vrijwel zonder uitzondering verbinden met de oproep tot een natuurlijke leefwijze. Die samenhang treedt uiteraard duidelijk aan het licht bij de vele volgelingen van Wagner en wel met name binnen de zogenaamde Bayreuther Kreis. De roep om een "reine Kunst" wordt in de Bayreuther Blatter, het orgaan van de Wagnercultus, ondersteund door verscheidene bijdragen over vegetarisme, anti-vivisectionisme, geheelonthouding en rassenhygiëne. ${ }^{\text {GS }}$ Een soortgelijke mengeling van mystiek, antisemitisme en Lebensreform is aanwijsbaar bij de schilder en illustrator Fidus. En ook bij hem worden deze uiteenlopende interessen verbonden door een alles overheersend verlangen naar zuiverheid. "Schönheit" en "Reinheit" vormen de leidende thema's van zijn werk, dat in de herinnering van een naaste vertrouwelinge werd gekenmerkt door de daarin aanwezige "Reinheitskraft", die "aus dem Urborn der Reinheit" werd geput en die, "Reinheit glaubend, Reinheit schaffend", de Duitse toekomst zou voorbereiden. ${ }^{66}$

De opkomst van racistische en antisemitische voorstellingen onderstreept de teloorgang van het Duitse Idealisme, dat binnen de Kultur - und Lebensreformbewegung veelal verwatert tot -wat Fritz Stern heeft genoemd- Vulgaridealismus. De Kultur- und Lebensreformbewegung vertoont evenwel vele schakeringen en is zeker niet in al haar geledingen door het virus van het racisme aangetast.

64 Over die aandacht voor -m.n. anale- onreinheid: vgl. b.v. A. Just, o.c., p. 100. Zie ook: A. Dundes, Life is like a chicken coop ladder. A portrait of German culture through folklore. (New York/Guildford 1984), passim: Dundes verdedigt de stelling, dat in de Duitse cultuur in het algemeen sprake is van een verhoogde belangstelling voor het anale. Hij wordt daarin gevolgd door B. Nuss, o.c., p. 95 e.v.

${ }^{65} \mathrm{Vgl}$. W. Schüler, o.c., p. 145-146, 212-213 en 273.

${ }^{66}$ Geciteerd bij: J. FrecotJJ.F. Geist/D. Kerbs, Fidus, 1868-1948. Zur dsthetischen Praxis burgerlicher Fluchtbewegungen. (München 1972), p. 103 en 196. 
In Julius Langbehn's Rembrandt als Erzieher speelt het thema bijvoorbeeld, ongeacht de "völkische" toonzetting en de ook hier aanwezige aandacht voor "die Macht des Blutes", geen opvallende rol. En hetzelfde geldt voor het invloedrijke, door Ferdinand Avenarius geredigeerde blad Der Kunstwart. ${ }^{67}$ Desalniettemin bevestigen deze voorbeelden in het algemeen toch het hier geschetste beeld. Op deze plaats is het dan ook beter om het oog te richten op een figuur, die zich enigszins terzijde bevindt: op Friedrich Nietzsche, wiens werk enerzijds verwantschap toont met de doelstellingen van de Kultur- und Lebensreformbewegung, maar die zich tegelijk scherp heeft afgezet tegen vele van de hier verkondigde opvattingen. Zelfs een beknopte -al te beknopte- bespreking toont, hoezeer het verlangen naar zuiverheid ook zijn denken heeft beheerst.

Dat verlangen spreekt bijvoorbeeld uit een passage in Ecce Homo, waarin Nietzsche wijst op een karaktertrek van zijn persoonlijkheid, die zijn omgang met anderen behoorlijk heeft vergald:

"Mir eignet eine vollkommen unheimliche Reizbarkeit des Reinlichkeits-Instinkts, so daß ich die Nähe oder -was sage ich?- das Innerlichste, die 'Eingeweide' jeder Seele physiologisch wahrnehmerieche...der viele verborgene Schmutz auf dem Grunde mancher Natur, vielleicht in schlechtem Blut bedingt, aber durch Erziehung übertüncht, wird mir fast bei der ersten Berührung schon bewußt. ${ }^{n 68}$

Ook Nietzsche beschikt over een sterk ontwikkeld reukorgaan, dat hem in staat stelt om de onreinheid van "de anderen" op afstand te signaleren. De neus is -althans in zijn beeldtaal- het krachtigste instrument van zijn "Pathos der Distanz", waardoor de natuurlijke rangorde der mensen wordt vastgesteld. Reinheid wordt zo tot een

${ }^{67}$ Vgl. J. Langbehn, Rembrandt als Erzieher. Von einem Deutschen. (Leipzig 1890), p. 127; F. Stern, The political consequences of the unpolitical German (1963), in: idem, The failure of illiberalism (New York 1972), p. 325; G. Kratzsch, Kunstwart und Dürerbund. Ein Beitrag zur Geschichte der Gebildeten im Zeitalter des Imperialismus. (Göttingen 1969), p. 306-321.

${ }^{68}$ F. Nietzsche, Werke Bd. 1-3 (München 1969; hrsg. von K. Schlechta) Bd. 2, p. 1080 . 
standskenmerk, dat echter ook in Nietzsche's voorstelling fysiologisch wordt bepaald. Niets onderscheidt twee mensen zozeer als "ein verschiedener Sinn und Grad der Reinlichkeit". De reine is daarbij de hoge, uitzonderlijke mens en in het bijzonder de heilige, in wie de behoefte aan lichamelijke hygiëne is gesublimeerd tot een drang naar geestelijke zuiverheid. Een geestelijke zuiverheid, die echter nog altijd wordt besmet door zijn medelijden "mit dem Schmutz des Menschlichen, Allzumenschlichen": met de onreine massa, die met een verwijzing naar het darmkanaal wordt gedesavoueerd. ${ }^{69}$ In Also sprach Zarathustra -door Nietzsche bestempeld als zijn "Dithyrambus auf die Einsamkeit, oder, wenn man mich verstanden hat, auf die Reinheit" - moet de gelijknamige profeet zich de neus toeknijpen om de stank van het vulgus af te weren. De vele onreinen vergiftigen de bron van het leven door hun zinnelijke wellust en smerige dromen. Dat is dan ook Zarathoestra's "walging": dat al deze onreinen bestaan en klaarblijkelijk noodzakelijk zijn. $^{\text {x }}$

Het medelijden van de heilige en de walging van Zarathoestra worden eerst overwonnen door de Übermensch, die zijn amor fati uitspreekt en zo het leven in al zijn vormen aanvaardt. Deze Übermensch verschijnt in het teken van de god Dionysos; hij is in zekere zin deze "kommende Gott", die de aankondiging vormt van de nakende crisis in de Europese beschaving. Die crisis heeft het karakter van een zuivering, van een katharsis zoals die op het beslissende moment optreedt in de Griekse tragedie, die uit de Dionysos-cultus werd geboren. Dionysos verbeeldt het proces van creatieve destructie, dat het leven -opgevat als Wille zur Machtvolgens Nietzsche is. Hij is niet alleen de god van de roes, van chaos en ontbinding en van de decadentie, die Nietzsche om zich heen ontwaart. Hij is ook Dionysos Zagreus, de god van de komende wedergeboorte, waardoor een nieuwe orde in het leven treedt. Zoals zijn tijdgenoten is ook Nietzsche gepreoccupeerd door het probleem van orde en chaos, dat telkens met het onderscheid tussen

${ }^{70}$ Ibid., p. 354-355 en 1080. 
het zuivere en het onzuivere blijkt te corresponderen. En ook in zijn geval is dat probleem ten nauwste verbonden met onzekerheid omtrent de eigen identiteit. Want zijn probleem is in laatste instantie toch "das Problem der Rangordnung (..), von dem wir sagen dürfen, daß es unser Problem ist": de vraag, hoe men de relatieve waarde van al die mensen kan bepalen en de eigen aanspraak op een leidende rol kan legitimeren. Het is deze drang om zich van de anderen te onderscheiden, die in het verlangen naar zuiverheid tot uitdrukking komt. ${ }^{71}$

Ook Nietzsche's ideaal is nog het individu, dat in harmonie verkeert met zichzelf en de wereld, en dat zich zo -zoals Humboldt het ooit formuleerde- tot "Symbol des Weltalls" heeft verheven. ${ }^{2} \mathrm{Bij}$ hem wordt dat ideaal evenwel geprojecteerd op de Übermensch; het heeft een bovenmenselijk karakter en wordt niet gerealiseerd via natuurlijke Bildung, maar door een lang proces van Zucht und Zuchtung: door een voortdurende zelfdwang en zelfoverwinning, waarbij het individu zich in het eigen vlees moet snijden om zijn driften in te tomen. ${ }^{73}$ Zucht und Zuchtung zijn noodzakelijk, opdat de "hogere mens", nieuwe "Führer", "eine stärkere Art" of "eine stärkere Rasse" wordt gecreëerd. De verschijning van de "hogere mens" mag niet langer aan het toeval worden overgelaten, maar dient op gecontroleerde wijze te worden bevorderd. ${ }^{74}$

71 F. Nietzsche, o.c. Bd. 1, p. 444. Vgl. W. Kaufmann, Nietzsche. Philosopher, psychologist, antichrist. (New York 1968; 1e druk 1950), p. 129. Over de Duitse Dionysos-cultus: J.H. Rosteutscher, Die Wiedergeburt des Dionysos. Der naturmystische Irrationalismus in Deutschland. (Bern 1947), m.n. p. 137-192; M. Frank, Der kommende Gott. Vorlesungen uber die neue Mythologie. (Frankfurt a.M. 1982), passim.

72 W. von Humboldt aan Chr. Körner, 8-6-1805, in: W. von Humboldt, Briefe (München 1952; Auswahl von W. Rössle), p. 271.

${ }^{73}$ Vgl. F. Nietzsche, o.c. Bd. 1, p. 902 (nr. 53) en 1275 (nr. 560) en Bd. 2, p. 168-169 (nr. 290). Zie ook: W. Kaufmann, o.c., p. 304-306.

74 Vgl. F. Nietzsche, o.c. Bd. 2, p. 661-662 (nr. 203), 689-690 (nr. 225), 1111 en 1166 en $B d$. 3, p. 468, 505, 521 en 810. Zie ook: M. Onfray, Le ventre des philosophes. Critique de la raison diététique. (Paris 1989), p. 104. 
Zucht und Zachtung omvatten derhalve een eugenetisch program$\mathrm{ma}$, dat is verbonden met strenge diëtistische en hygiënische voorschriften. Nietzsche is een ware "filosoof van de buik": de fysiologie vormt het uitgangspunt van zijn denken. De filosoof is in zijn ogen als een arts, die alle psychologische, morele en ideële verschijnselen beziet als de uitdrukking van lichamelijke behoeften. De geestelijke toestand reflecteert de lichamelijke constitutie en wordt vooral bepaald door stofwisseling en spijsvertering. Met die opmerkelijke belangstelling, die ook de Kultur- und Lebensreformer kenmerkt, verklaart Nietzsche de Duitse Geist "aus betrübten Eingeweiden"; de Duitse geest is een indigestie: "er wird mit nichts fertig". Evenzo wordt de Europese decadentie omschreven als een vorm van geestelijke constipatie, als "die schwarze Traurigkeit der Physiologisch-Gehemmten". ${ }^{75}$

Nietzsche's eigen voorschriften op het terrein van dieet, hygiëne en sexualiteit hebben een puriteins, ascetisch karakter. Zij getuigen van zijn behoefte om het eigen lot te controleren en vorm te geven. Maar in tegenstelling tot de meeste Kultur- und Lebensreformer is hij niet doctrinair: hoewel hij getuigt van zijn afkeer van vet- en meelspijzen, alcohol, koffie en tabak, en een natuurlijke kuisheid als het kenteken van de "hogere mens" lijkt te beschouwen, predikt hij in laatste instantie toch een "science de la mesure", waarbij ieder individu de eigen maat moet trachten te vinden. ${ }^{76}$ Belangrijker nog is het feit, dat het begrip "Rasse" door hem op een tamelijk losse wijze wordt gebruikt. Hoewel hij uitgaat van de erfelijkheid van eigenschappen en zich in die zin beroept op het bloed, keert hij zich vooral in latere jaren fel tegen diegenen, die het begrip "Ras-

${ }^{75}$ F. Nietzsche, o.c. Bd. 2, p. $871-872$ en 1083 . Vgl. idem, o.c. Bd. 1 , p. 1150 (nr. 202) en 1180 (nr. 269) en Bd. 2, p. 11 (nr. 2), 241 (nr. 368), p. 912-918 (nr. 5-7) en 1085.

${ }^{76} \mathrm{M}$. Onfray, Le ventre des philosophes, p. 103. Een gedetailleerde behandeling van Nietzsche's "regime" is hier helaas niet mogelijk: vgl. F. Nietzsche, o.c. Bd. 2, p. 318-319, 912 en 1082-1085 en Bd. 3, p. 795 en 923-924. Zie ook: C.P. Janz, Friedrich Nietzsche. Biographie. (München 1978) Bd. 1, p. 341-342 en Bd. 2, p. 21-24 en 535-537. 


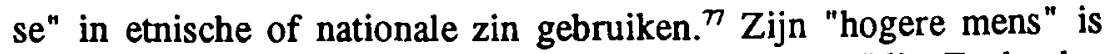
het krachtige individu, dat wordt gekenmerkt door "die Zucht des Leidens", dat ten grondslag ligt aan alle grootse scheppingen. ${ }^{78}$ Hoewel ook zijn denken wordt gekenmerkt door een verregaande mate van mixofobie, heeft deze angst in zijn geval geen betrekking op etnische en nationale groepen, maar op een bepaald type mens: op het gedegenereerde "Herdentier", dat de westerse massamaatschappij bevolkt, en dat een gevaar vormt voor de "hogere mens". En zo groot is deze angst en zo ruim zijn definitie van dit kuddedier, dat uiteindelijk slechts de diepste eenzaamheid resteert. Zarathoestra wil geen volgelingen: dat is de uiterste vorm van zelfverheffing en de consequentie van het tot in het extreme doorgevoerde "Reinlichkeits-Instinkt".

\section{Een voorlopige balans}

Daarmee kom ik aan het slot van mijn betoog. Mijn doelstelling was het belang te tonen van een thema, dat door historici tot nu toe niet systematisch werd onderzocht: het verlangen naar zuiverheid. Mijn opzet was vooral om aannemelijk te maken, dat dit verlangen de verbindende schakel vormt tussen diverse verschijnselen -zoals Idealisme, hygiënisme, Lebensreform en ook racisme-, die doorgaans los van elkaar worden beschouwd. De verschillen tussen deze verschijnselen worden, zoals opgemerkt, geenszins ontkend; zij zijn niet louter bijkomstig en, vanuit een andere optiek beschouwd, zelfs essentieel. Tegelijk echter lijken zij, als uitingsvormen van het verlangen naar zuiverheid, ook de nodige overeenkomsten te vertonen. Vanuit dat oogpunt bezien lijken zij te ontspringen aan soortgelijke drijfveren en motieven, die eenzelfde geestesgesteldheid -dat is: perceptiewijze en sociaal-psychologische mentaliteit- doen ver-

77 Nietzsche's vroegere houding -met name tegenover joden- is minder eenduidig: vgl. F. Nietzsche, o.c. Bd. 1, p. 1182 (nr. 272), Bd. 2, p. 253 (nr. 377), 653 (nr. 195), 656-657 (nr. 200), 716-717 (nr. 251), 952 (nr. 3), 1210-1211 (nr. 46), 1220 (nr. 53) en 1223 (nr. 55), en Bd. 3, p. 430 en 1297.

${ }^{78}$ F. Nietzsche, o.c. Bd. 2, p. 689-690 (nr. 225). Vgl. ibid., p. 661-662 (nr. 203) en 116 en $B d .3$, p. 468, 505, 521 en 810.

79 Vgl. F. Nietzsche, o.c. Bd. 2, p. 339-340 en 1080 (nr. 8). 
moeden. Die geestesgesteldheid vormt hier het onderwerp en in het voorgaande zijn ook reeds enige gezichtspunten aangereikt, die kunnen bijdragen tot een beter begrip hiervan.

Het is hier echter, aan het begin van een nieuw onderzoek, niet de plaats voor vergaande conclusies. De beperkingen van de voorgaande case-study zijn daarvoor ook te duidelijk. Het Duitse Reinheitsideal is niet gebonden aan de hier besproken personen en stromingen. De traditie van het Duitse verlangen naar zuiverheid kan verder worden gevolgd in het verleden, bijvoorbeeld tot de Hervorming en de zo belangrijke figuur van Luther. Zij kan ook worden doorgetrokken tot in de twintigste eeuw, en in het bijzonder tot het nationaal-socialisme en de persoon van Hitler. Zij zou ook, meer dan hier is geschied, kunnen worden onderzocht vanuit het perspectief van de mentaliteitsgeschiedenis, waarbij aandacht kan worden besteed aan reinheidsvoorschriften bij eten en drinken, bijvoorbeeld aan het altijd nog actuele Reinheitsgebot voor het bier. En belangrijker nog: zij zou binnen een breder, vergelijkend kader kunnen worden geplaatst. Want dit verlangen naar zuiverheid is immers, zoals opgemerkt, niet "typisch Duits". Hoewel het vermoeden gerechtvaardigd lijkt, dat dit verlangen zich in het moderne Duitsland in relatief sterke mate heeft gemanifesteerd, is het toch ook elders duidelijk aanwijsbaar. Men denke aan Rousseau en zijn revolutionaire geestverwanten, aan de Engelse purity-movements, aan Nederlandse hervormingsbewegingen zoals de Rein Leven Beweging, en -in een meer recent verleden- aan de wijd verbreide Tolkien-cultus. Eerst binnen een dergelijk comparatief kader, waarin aandacht wordt besteed aan -met name- Engeland, Frankrijk en Nederland, kan ook het moderne Duitse Reinheitsideal afdoende worden begrepen. ${ }^{80}$

${ }^{80}$ Zie voor Engeland b.v.: E.J. Bristow, o.c., passim, en E. Trudgill, Madonnas and Magdalens. The origins and development of victorian sexual attitudes. (London 1976). Voor Nederland kan onder meer worden gewezen op: A. de Groot, "De weg tot kuisheid voert door de nuchterheid". De Rein Leven Beweging in Nederland, 1901-1930. (Groningen 1983): het betreft hier een niet gepubliceerde scriptie M.O.-B Geschiedenis van de Noordelijke Leergangen. 
Desalniettemin levert deze case-study wel enige gezichtspunten, die kunnen bijdragen tot de interpretatie van het verlangen naar zuiverheid en die zo de richting kunnen wijzen voor voortgezet onderzoek. Een dergelijke interpretatie voltrekt zich mijns inziens op drie niveau's. Het eerste niveau wordt daarbij bepaald door het perspectief van de culturele antroplogie. Op dit niveau kan worden geconstateerd, dat het Duitse Reinheitsideal deel uitmaakt van een breder patroon. Dat wil zeggen dat burgers van een moderne samenleving die greep trachten te krijgen op hun wereld, daarbij in feite gebruik maken van een classificatieschema dat toch op het eerste gezicht kenmerkend leek voor primitieve beschavingen. Het Duitse Reinheitsideal bevestigt de stelling van Mary Douglas, dat het verlangen naar reinheid en zuiverheid de uitdrukking vormt van een streven naar orde, voortkomend uit de angst voor verandering, ambiguïteit, chaos en vermenging, die het gevoel van identiteit bedreigen en worden samengevoegd onder de noemer "degeneratie". Het bevestigt bovendien de opvatting, dat dit verlangen bij voorkeur wordt geprojecteerd op het lichaam, dat daarmee tot het symbool wordt van de individuele, sociale, nationale of raciale identiteit.

Overeenkomsten vormen in de cultuurwetenschappen echter -ten onrechte- zelden de inzet van een verklaring: zij worden doorgaans als een gegeven aanvaard. Verklaringen richten zich meestal op de verschillen, die een dergelijke aandacht klaarblijkelijk meer waard zijn. Daarmee belanden wij dan op het tweede niveau, waarbij het verlangen naar zuiverheid vanuit een sociaalhistorisch perspectief wordt bezien. Zoals opgemerkt vormt de persoonlijke identiteit in de pre-industriële samenleving nog in hoge mate een sociaal bepaald gegeven, dat vooral berust op het geboorteprincipe. Vanaf het einde van de achttiende eeuw maakt deze relatief statische, agrarische samenleving plaats voor de moderne, industriële massamaatschappij, die vooral wordt gekenmerkt door haar dynamisch karakter. Zonder in details te treden, mag toch worden opgemerkt dat dit moderniseringsproces zich nergens met zoveel kracht en in zo'n hoog tempo heeft voltrokken als in Duitsland, dat met name na 1870 door een snelle opeenvolging van maatschappelijke veranderingen wordt getroffen. Het ligt voor de hand om de verhoogde 
belangstelling voor zuiverheid, die zo kenmerkend lijkt voor het negentiende-eeuwse Duitsland, in het licht van deze sociaalhistorische situatie te bezien. Vooral die groepen, die in hun maatschappelijke positie worden bedreigd, lijken geneigd om hun onzeker geworden identiteit scherp af te bakenen. Zij beklemtonen de grenzen tussen zichzelf en de anderen en formuleren dit onderscheid in termen van zuiverheid. Dit verband is reeds aanwijsbaar in het Bildungsidealismus, dat een antwoord vormt op de gevaren van de Franse Revolutie. Het wordt manifest in de Kultur- und Lebensreformbewegung, waar het verlangen naar zuiverheid een nationalistische en, vaak zelfs, racistische wending neemt.

De geschiedenis van maatschappelijke structuren behoudt echter een abstract karakter. De betekenis van sociaalhistorische veranderingen wordt pas ten volle zichtbaar op het derde en laatste niveau: in het afzonderlijke individu, dat in hoge mate door deze omgeving wordt gevormd en waarin dergelijke veranderingen derhalve een concrete gestalte aannemen. Het sociaalhistorische perspectief moet dan ook mijns inziens bij voorkeur worden verbonden met een psychobiografische benadering. Vooral de geschiedenis van gezin en opvoeding biedt in dit verband de nodige aanknopingspunten. Gezin en opvoeding vormen immers de kanalen, waarlangs sociale normen en waarden worden overgedragen op het kind, dat zich eerst zo ontwikkelt tot een volwaardig individu. Het geval Wagner illustreert mijns inziens het belang van dergelijk onderzoek, dat gemakkelijk tot anderen -zoals Rousseau, Gobineau en Nietzschekan worden uitgebreid en dat de aandacht zou verdienen van professionele psychohistorici.

Het verlangen naar zuiverheid speelt een cruciale rol in de meest uiteenlopende beschavingen. Zelfs een korte blik op de geschiedenis volstaat voor deze conclusie: dat mensen telkens opnieuw zijn gefascineerd door dit ideaal, dat zij op zeer verschillende wijzen hebben nagestreefd. Het verlangen naar zuiverheid ligt ten grondslag aan godsdienstige en utopische bewegingen, en doordringt het werk van filosofen, schrijvers en kunstenaars, die hierdoor werden geïnspireerd tot grootse en alleszins bewonderenswaardige creatieve daden. Desalniettemin schuilt in deze blinde fascinatie tevens een gevaar. Het verlangen naar zuiverheid vormt immers ook de brand- 
stof voor nationalistische en racistische bewegingen, die in naam hiervan anderen uitsluiten en vervolgen. Hier ligt een vraag: de vraag naar het verband tussen deze verschillende vormen, waarin het verlangen naar zuiverheid zich manifesteert. Sedert ik drie jaar geleden, tijdens een werkgroep, op dit thema werd geattendeerd, heeft deze vraag mij bezig gehouden. Het is de vraag naar het verband tussen de Kant van de Kritik der reinen Vernunft en de Kant van de Bestimmung des Begriffs einer Menschenrace of naar de relatie tussen Bildungsidealismus, hygiënisme en racisme. Het hier gesuggereerde verband heeft geen finalistisch karakter: het gaat hier niet om een bekende vorm van genealogisch denken, waarbij de wortels van het nationaal-socialisme worden getraceerd tot personen als Kant en Humboldt, die onmogelijk verantwoordelijkheid kunnen dragen voor een beweging die pas ver na hun dood is ontstaan. Zoals de hier gekozen "archeologische" benadering suggereert, beweegt het verlangen naar zuiverheid zich op een niveau, dat zich grotendeels onttrekt aan de sfeer van bewuste overwegingen en persoonlijke keuzes. Daarin schuilt ook het ware gevaar: het betreft hier een figuur in het collectieve denken, die bepalend is voor een hele cultuur en waaraan het individu zich moeilijk kan onttrekken. Een cultuur die dat verlangen beklemtoont of zelfs tot ideaal verheft, heeft geen controle over de wijze, waarop het zich uit. Het verlangen naar zuiverheid moet primair worden beschouwd als een geestesgesteldheid, die het denken in formele zin structureert: een mentale vorm, die in inhoudelijk opzicht de nodige variaties kan vertonen. Wat als een verlangen naar spirituele zuiverheid begint, kan dan ook -onder veranderde maatschappelijke voorwaarden- eindigen in xenofobie en rassenhaat. In een tijd, waarin pogingen tot genocide weer aan de orde van de dag zijn en op beleefde wijze worden aangeduid door de term "etnische zuivering", verdient deze samenhang zeker nadere aandacht; een samenhang, waarvoor de schrijver Salman Rushdie ons waarschuwt, wanneer hij opmerkt:

"Zuiverheid is het gevaarlijkste woord op deze planeet. Waar dat opduikt volgt Auschwitz." ${ }^{81}$

${ }^{81}$ De Volkskrant, 12-11-1993. 


\section{Nawoord}

Mijn dankwoord is zo kort als mijn dank groot is. Ik denk met de beste herinneringen terug aan mijn vrienden en collega's van het Historisch Seminarium te Amsterdam en in het bijzonder aan Maarten Brands, die mij vanaf mijn studietijd tot steun is geweest. Ik ben blij, dat wij onze samenwerking op het terrein van het onderzoek kunnen voortzetten en wel met name via de projectgroep, die rond het thema "zuiverheid" is geformeerd en waaraan ook leden van mijn nieuwe vakgroep deelnemen.

Van mijn Amsterdamse studenten heb ik veel geleerd. Het is niet toevallig, dat het idee voor deze rede tijdens een van mijn colleges is geboren. Belangrijker echter is dat zij in hoge mate hebben bijgedragen aan het plezier, dat ik in mijn werk heb gevonden.

Ik ben het College van Bestuur en het Bestuur van de Faculteit der Cultuurwetenschappen van de Rijksuniversiteit Limburg erkentelijk voor het vertrouwen, dat zij door mijn benoeming in mij hebben getoond. Mijn dank geldt voorts de medewerkers van Cultuur- en Wetenschapsstudies en in het bijzonder mijn collega's van de vakgroep Geschiedenis en het daarmee verbonden secretariaat. Dankzij hen is de overgang naar het Zuiden mij veel gemakkelijker gevallen dan ik ooit had durven hopen. Het is een voorrecht om met hen te kunnen werken aan de opbouw van een nieuwe faculteit. Het succes van die faculteit zal worden bepaald door de belangstelling van de studenten. Ik hoop vanuit mijn vakkennis bij te dragen aan hun opleiding en omgekeerd -zoals dat in Amsterdam het geval was- van hun reacties te profiteren. Mijn ervaringen van de afgelopen maanden geven mij alle vertrouwen, dat die hoop bewaarheid wordt.

Mijn vrienden en familie ben ik meer verschuldigd dan ik hier in woorden kan uitdrukken. Ik noem in het bijzonder Florike Egmond: een goede vriendin en een stimulerende gesprekspartner. Maar bovenal denk ik uiteraard aan Solange Leibovici, die een belangrijke bron van inspiratie voor mij is geweest. Wie ons beiden kent en deze rede heeft aangehoord, weet hoeveel van mij eigenlijk van haar is. Die rede is, tenslotte, opgedragen aan mijn kinderen, Nanon en Charlotte. Het is niet meer dan een onbeholpen manier om te zeggen, hoe belangrijk zij voor mij zijn.

Dames en heren, ik dank u voor uw aandacht en aanwezigheid. 